\title{
ICTs and Poverty Eradication: Comparing Economic, Livelihoods and Capabilities Models
}

Link to publication record in Manchester Research Explorer

\section{Citation for published version (APA):}

Heeks, R. (2014). ICTs and Poverty Eradication: Comparing Economic, Livelihoods and Capabilities Models. (IDPM Development Informatics Working Papers; No. 58).

http://www.seed.manchester.ac.uk/subjects/idpm/research/publications/wp/di/di-wp58/

\section{Citing this paper}

Please note that where the full-text provided on Manchester Research Explorer is the Author Accepted Manuscript or Proof version this may differ from the final Published version. If citing, it is advised that you check and use the publisher's definitive version.

\section{General rights}

Copyright and moral rights for the publications made accessible in the Research Explorer are retained by the authors and/or other copyright owners and it is a condition of accessing publications that users recognise and abide by the legal requirements associated with these rights.

\section{Takedown policy}

If you believe that this document breaches copyright please refer to the University of Manchester's Takedown Procedures [http://man.ac.uk/04Y6Bo] or contact uml.scholarlycommunications@manchester.ac.uk providing relevant details, so we can investigate your claim.

\section{OPEN ACCESS}




\title{
Development Informatics
}

\section{Working Paper Series}

The Development Informatics working paper series discusses the broad issues surrounding information, knowledge, information systems, and information and communication technologies in the process of socio-economic development

Paper No. 58

\section{ICTs and Poverty Eradication: Comparing Economic, Livelihoods and Capabilities Models}

\author{
RICHARD HEEKS
}

2014

ISBN: 978-1-905469-85-7

Published Centre for Development Informatics

by: $\quad$ Institute for Development Policy and Management, SEED

University of Manchester, Arthur Lewis Building, Manchester, M13 9PL, UK

Email: cdi@manchester.ac.uk Web: http://www.cdi.manchester.ac.uk

View/Download from:

http://www.seed.manchester.ac.uk/subjects/idpm/research/publications/wp/di/

Educators' Guide from:

http://www.seed.manchester.ac.uk/subjects/idpm/research/publications/wp/di/educdi/ 


\section{Table of Contents}

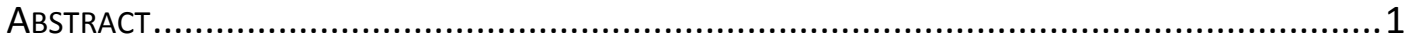

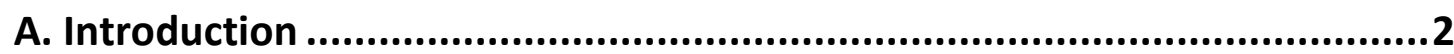

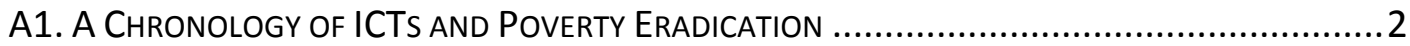

B. Mapping the Relation Between ICTs and Poverty Eradication ..................5

C. Conceptualising the Relation Between ICTs and Poverty Eradication.........9

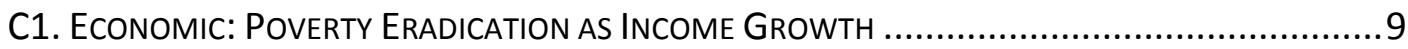

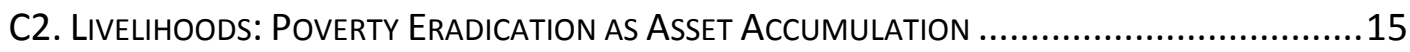

C3. Capabilities: Poverty Eradication as Greater Role Freedom ................................. 18

C4. StRENGTHS ANd WEAKNESSES OF PeRSPECTIVES.....................................................24

D. Summary and Implications ........................................................26

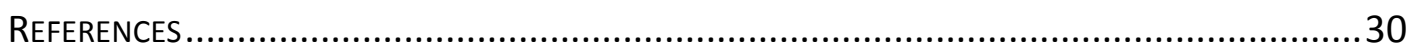




\title{
ICTs and Poverty Eradication: Comparing Economic, Livelihoods and Capabilities Models
}

\author{
Richard Heeks \\ Centre for Development Informatics \\ IDPM, University of Manchester, UK \\ Email: richard.heeks@manchester.ac.uk
}

2014

\begin{abstract}
From the MDGs to the post-2015 development agenda, poverty eradication is arguably the single most important development goal. This paper asks how information and communication technologies can contribute to that goal. ICTs mobile phones especially - have diffused rapidly in developing countries in recent years, and now reach increasingly into the lives of the world's poor.

Research assessing the poverty impacts of that diffusion has been relatively limited; in part because this change has been so recent. Research has also sometimes been constrained by its lack of conceptual foundation. The purpose of this paper is therefore to assess research evidence within a framework that conceptualises both poverty eradication and ICT application.

It does this by identifying three categories of ICT application - other ICT uses, enterprise ICT use, and ICT sector use. And by identifying three perspectives on poverty eradication - economic, livelihoods, and capabilities. It suggests that moving across the categories of application may lead to deeper poverty impacts; but impacts which affect a smaller number of people. And that moving across the perspectives may provide a fuller understanding of poverty; particularly in developing the capabilities approach to understand the ladder of "roles" through which poor people can engage with ICTs.
\end{abstract}

The paper ends by suggesting some implications for policy and practice. 


\section{A. Introduction}

Poverty is most readily defined in financial terms. On this basis, in 2010 , some $1.2 \mathrm{bn}$ people in the developing world - around one fifth of the population - were living on less than US\$1.25 per day, and 2.4bn (roughly 40\%) were living on less than US\$2 per day (DI 2013). Given this prevalence, poverty eradication - reduction to zero in numbers of those living below one of the defined poverty lines - has been a key development objective. It is the first of the Millennium Development Goals and it will be central to the post-2015 development agenda (Heeks 2014a).

Yet the argument has been made that the intellectual engagement between information and communication technologies (ICTs) and poverty eradication has been too limited to date and that "ICT may remain somewhat sidelined [from the mainstream of international development] unless that engagement can be made, speaking to both financial and broader notions of poverty" (Heeks 2014b: 12).

The aim of this paper is to review key aspects of that engagement to date; to help guide those wishing to understand the connections between ICTs and poverty eradication. It can be read as an update of Heeks (1999).

Section B develops an overview map of the various ways - economic and noneconomic, direct and indirect - in which ICTs relate to poverty. It identifies three main categories of ICT application of relevance to poverty eradication: other ICT use, enterprise ICT use, and ICT sector. Section C then outlines three key models for conceptualisation of poverty: economic, livelihoods, and capabilities. It reviews evidence about the impact of ICTs on poverty from these three perspectives, and summarises the strengths and weaknesses of each model. Section D summarises what has been learned about applications and conceptual models that link ICTs and poverty, and briefly outlines some implications for policy and practice.

\section{A1. A Chronology of ICTs and Poverty Eradication}

The contribution of ICTs to poverty eradication has evolved over time.

First use of ICTs for development (ICT4D) can be traced back to 1956, and the installation of a computer to support analysis for government planning in the Indian Institute of Statistics (Heeks 2009a) ${ }^{1}$. Although only the first example, this was typical of ICT4D application during the 1960s and 1970s: internal use within government organisations for data processing and management information system purposes that had little to do with poverty. Such uses continue to this day but they were joined in the 1970s and 1980s by similar applications in large public and private sector enterprises. Again, during this phase that can be characterised as "ICT4D 0.0", there was little direct connection to delivery of development goals including poverty

\footnotetext{
${ }^{1}$ First use of communication for development can be traced further back, to radio stations in Latin America and South Asia in the 1940s broadcasting with the intention of assisting rural development (Manyozo 2006).
} 
eradication and no direct connection to the lives of the poor (Heeks 2009b). ICTs remained well back from the development "front line", and the role of the poor was clear: they were non-users.

Two things changed in the mid-1990s in order to usher in ICT4D 1.0: the first phase in which digital technologies were steered directly towards development goals ( $i b i d)$. A clear and simple set of objectives - later known as the Millennium Development Goals - was identified and promoted. They became ends in search of means. And the Internet began to diffuse into developing countries: a means in search of ends. These two came together in a whole series of policies, strategies, programmes and projects, the epitome of which was the telecentre: typically one or two Internetlinked PCs that could deliver livelihoods-related, web-based information into poor communities.

The role of the poor therefore changed. Telecentres were still relatively rare, so only a few at the base of the pyramid became direct users of the new technology. Where they did so, they were generally consumers of "broadcast" information - searching for and ingesting fairly general information about health, or education, or government services which might or might not then lead to some development action (Jensen \& Esterhuysen 2001, Etta \& Parvyn-Wamahu 2003). More often - and given the spread of ICTs into local government, NGOs and even some communitybased organisations - the poor were indirect users; informed by some Internetconnected intermediary acting on their behalf.

As the 2000s proceeded, though, the character of ICT4D 1.0 began to alter. In part due to technological change, with the telecentre PC now increasingly overtaken by the mobile phone as the dominant ICT4D conduit. And in part due to technological diffusion. In 1998, one of every 100 inhabitants in a developing country was an Internet user (ITU 2014). By 2013, that figure was estimated to have risen to 31 per 100 , and annual growth rates have been over $15 \%$ per year.

The rise for mobile phone subscriptions has been even greater: the number of subscriptions was equivalent to $2 \%$ of the developing world's population in 1998 (ibid). Fifteen years later in 2013, that figure was estimated to have risen to $89 \%$, representing an annual growth rate of $29 \%$ per year ${ }^{2}$. Estimates suggest that actual mobile ownership might be around three-quarters of the subscription rates (due to lapsed and multiple subscriptions) (Heeks 2009c). However, those same estimates suggest actual usage - due to shared use of mobiles - to be much higher. This means that availability of mobiles is close to ubiquitous in many developing countries; a notion supported by field data from the lowest-income group in a sample of Asian countries indicating $95 \%$ of adults had made at least one phone call in the previous three months (de Silva et al 2008).

\footnotetext{
${ }^{2}$ Though growth rates have fallen towards the end of this period; to well under $10 \%$ per annum at the time of writing.
} 
Of course serious inequalities of ICT access and use remain: of location, age, gender, education and - often underpinning all four others - income. Some of the poorest countries e.g. in Africa still have a significant mobile divide (e.g. Alzouma 2013). For example, Internet usage rates in 2013 were well under 10 per 100 population in the poorest quartile of countries by GDP per capita (ITU 2014; see also Box 1 below). And the spotlight on mobile and PC/Internet should not hide the fact that progress with both older and newer technologies has been more limited. Fixed telephony rose from 6 lines per 100 inhabitants in developing countries in 1997 to peak at around 16 in 2007 but has then fallen back to nearer 11 in 2013 (ibid). In 2013, even though growth rates are high, broadband subscription levels were equivalent to less than $10 \%$ of the population in Africa (ibid; see also TBC 2013). Likewise, mobile Internet shows developmental promise as technologies converge, but its current accessibility to low-income groups is very limited (Sey et al 2013).

Taking an overall view, it may be premature to talk of being in a new "ICT4D 2.0" phase, but the developing world stands at least at the threshold of this new phase. Mobile phones are close to ubiquitous, even in low-income countries and communities, and they put digital tools into the hands of the world's poor for the first time, and provide links to a broader digital infrastructure. There is some Internet access in some of these communities and growth rates are strong. Put together, new roles for the poor can now be seen. These move beyond that of indirect user or passive consumer to being more engaged with the technology in various ways. In the remainder of this paper, these changes will be analysed further. 


\section{B. Mapping the Relation Between ICTs and Poverty Eradication}

Given the changes that are occurring, there is a need to map out the field of relations between ICTs and poverty eradication. In order to do this, some of the themes identified in Section A can be drawn out:

- Where, during earlier uses of ICTs, the technology would only have an indirect impact on the lives of the poor; now they are increasingly direct users of the technology. Direct use may have a different impact to indirect use.

- Many earlier uses of ICTs were associated with government and can be seen as often connected more with social development or with the broader development context. Only later was ICT applied in a way that had an immediate link to economic development; particularly to business and enterprise. Given the obvious association of economic development with poverty eradication (though see the discussion in Section $\mathrm{C}$ ), there may be a different impact between usage for economic and usage for non-economic development; to the extent those can be disentangled.

- There are two categories of ICT use that need to be distinguished. The great majority of ICT application takes an existing activity and alters it in some way through digitisation; perhaps reducing its cost or improving its quality. On the other hand, ICTs may give rise to some new activities that did not exist before ICTs. The main example of the latter would be anything that falls into the ICT sector, from manufacture of hardware to writing software to selling mobile phones to providing computer training. There could be different impacts between these ICT sector and non-ICT sector categories of use.

- Finally, within the category of existing activity uses, a distinction can be made between uses applied by the poor to income-generating enterprises, and other uses of ICT. Yet again, one might anticipate different impacts comparing these two sub-categories of ICT application.

From this foundation, an overall conceptualisation of the relations between ICTs and poverty eradication can be drawn up, as shown in Figure 1. 
Greater Depth of Effect?

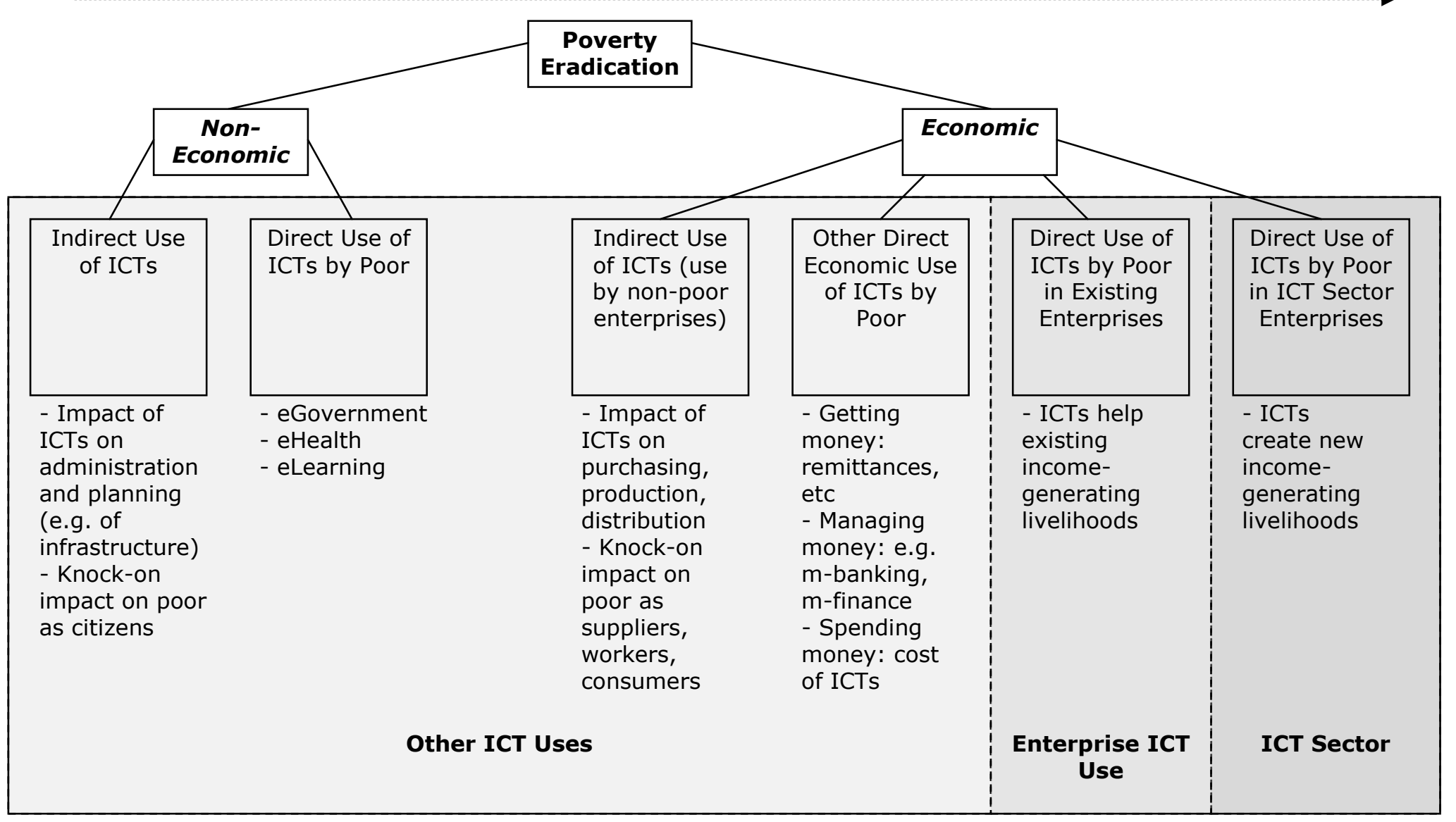

Figure 1: Conceptual Map of ICTs and Poverty Eradication 
As can be seen from Figure 1, indirect uses of ICT could be:

- Non-economic: typically internal use within the public sector or international agencies or NGOs, in a way that affects the organisation but does not lead to direct usage by poor communities. An example might be use of ICTs to assist policy-making within a government department.

- Economic: usage of ICTs by a private firm that is external, but in some way linked, to the poor community. An example might be use of ICTs to lower the cost of manufacture of goods sold to those communities.

Indirect usage is broad and mass-scale: for example, the majority of large organisations in developing countries will be users of ICT (whereas direct usage of ICTs by the poor, at least of computers and the Internet, is somewhat more restricted). However, the poverty effect of indirect usage is just that: indirect; providing only a rather distant backdrop. It will therefore not form any significant focus for this paper. By contrast, direct use of ICTs by the poor has a much more profound impact on individual lives in terms of financial costs and benefits. Compare, for instance, the impact on the poor of ICTs in large public and private organisations vs. the impact of telecentres in poor communities. As a result, it is the direct uses of ICTs within poor communities that will form the main focus for this paper.

The three main categories of direct ICT use to be investigated can therefore be summarised as follows:

- Other ICT Uses. These could be non-economic; typically an ICT-enabled information flow or transaction involving a user from a poor community. Increasingly this might involve their true direct use rather than the typical intermediated model in which the ICT is actually handled by, say, a local kiosk owner. An example might be an SMS reminder to a tuberculosis patient to take their medicine. These "other uses", though, could also be economic; that is, financial uses of ICTs by the poor which are not directly related to enterprise. Figure 1 gives examples of use of ICTs - especially mobiles - by dividing financial actions into three: getting money (such as facilitating the flow of remittances from urban to rural areas); managing money (such as use of mobiles to provide the "unbanked" with access to financial services); and spending money (a reminder that as well as delivering money to poor communities, ICTs also draw income away through expenditure: see Box 1 below).

- Enterprise ICT Use: the use of ICTs by the poor in their own micro-enterprises, but micro-enterprises which fall outside the ICT sector. An example would be use of a mobile phone by a cloth retailer or farmer to stay in contact with customers.

- ICT Sector: the use of ICTs by the poor to create a new income-generating livelihood. An example would be sales of mobile phone calls or of top-up cards. (A simple differentiator between this and the previous category is the question, "Could this enterprise activity exist without ICTs?" An answer "yes" means it falls into the "Enterprise ICT Use" category. An answer "no" means it falls into the "ICT Sector" category.) 
The argument was made above that in moving from indirect to direct uses of ICTs broadly, from left to right in Figure 1 - there might be a deeper impact but one that might affect more limited numbers. The same argument could be made - and, again, representing a move from left to right - first in comparing "Other ICT Uses" with the two enterprise categories. Anyone with a mobile can, in theory, use it to access social information or to facilitate a remittance transfer. But the poverty eradication impact could be relatively limited (assuming that, absent the mobile, the remittance might have happened in some other way). By contrast, fewer people will be in a position to use ICT to directly improve their income-generating livelihoods. But, if they can do so, ICTs may have a more significant poverty eradication effect.

The same applies in relation to non-ICT-sector vs. ICT-sector uses. The former, representing application of ICTs to existing activities, will tend to have a fractional impact on that activity; such as some improvement in productivity or quality. But the potential - covering all parts of the pre-ICT economy - is necessarily wideranging. By contrast, the creation of new ICT sector activities represents a much smaller part of the overall economy but the impact of ICT is not marginal; it centrally creates a complete new poverty-eradicating activity. Compare, for instance, the use of mobiles by traditional street vendors vs. the selling of mobiles by new street vendors.

One can conjecture, then, that moving along the three categories - as indicated at the top of Figure 1 - may reflect a move from greater breadth of ICT effect on poverty to greater depth of effect. It would seem strategically logical to invest across the board in all types of ICT application. However, which applications should attract most investment is still unclear because there is relatively limited evidence about the variation of poverty eradication (and other) impacts between the categories. The remainder of this paper will review some of this evidence, and offer a further - conceptual - way to categorise the relation between ICTs and poverty eradication. 


\section{Conceptualising the Relation Between ICTs and Poverty Eradication}

The previous section talked about breadth of impact and depth of impact, but did not discuss in any detail how to define that impact. Now turning to this issue, a starting point would be the earlier definition of poverty in simple income terms, and poverty eradication as a particular increase in daily income. However, poverty has increasingly been recognised as multi-dimensional (e.g. Addison et al 2008, Ferreira \& Lugo 2012). Poverty eradication can, likewise, be seen as more than simply economic. This paper therefore draws from ideas about the basis for development and poverty eradication (e.g. Ravallion 2004, Agola \& Awange 2014) and from related ideas about ICTs and poverty (e.g. Flor 2001, Duncombe 2007) and about ICT4D impact assessment (Heeks \& Molla 2009) to identify three different perspectives on poverty eradication:

- Economic: seeing income generation as the route to poverty eradication.

- Livelihoods: seeing poverty eradication as deriving from delivery of a variety of livelihood assets; not just money but also health, skills, information, etc.

- Capabilities: seeing poverty eradication deriving from development of greater freedom to act, encapsulated by the notion of "roles".

\section{C1. Economic: Poverty Eradication as Income Growth}

The longest-standing and most-fundamental understanding of development is to see it as an expansion of wealth, typically measured in terms of GDP per capita. On this basis, poverty is seen in its simplest terms as a lack of money, and the eradication of poverty is a strategy for delivering greater income to the poor.

Drawing on the conceptual map outlined in Figure 1, three different types of ICT application for this purpose can be identified:

Other ICT Uses: a common, albeit limited, financial gain associated with ICTs is a saving of money through journey substitution. Examples falling outside the enterprise and ICT sector applications could include migrants saving money because they feel less necessity to travel to their home villages (Mehta 2013), and citizens seeking services needing to travel less often to government offices (Bhatnagar \& Singh 2010). ICTs can also be used to deliver more substantial amounts of money. For example, figures from Africa show an unweighted average across 17 countries of $46 \%$ of mobile phone owners had received airtime as a financial transfer from a friend or family member (Comninos et al 2009). Where a more formal mobilemoney system is used, the typical average value of transfer is US\$35 (Duncombe 2012). ${ }^{3}$

\footnotetext{
${ }^{3}$ Of course, the phone is just a conduit here and the key question is whether any of this is "new" money that would not otherwise have been sent. There are good reasons to believe that the speed, security and low cost of mobile-enabled transfers do lead to an increase in the amount of money being sent to poor recipients (Godoy et al 2012). However, there are also questions of the utilisation
} 
Enterprise ICT Use: savings through journey substitution are a common benefit reported for those involved in production and trade since they can coordinate these activities without the need for physical meetings (Boateng et al 2014). Microentrepreneurs also make significant use of mobile money to receive payments (64\% of those questioned in Tanzania: Mawona \& Mpogole 2013) ${ }^{4}$. More substantially, ICTs can be used to help increase the income earned by micro-entrepreneurs. Jensen's (2007) much-cited work on mobiles and fishermen in Kerala, for example, shows phone users gaining an average Rs.205 (c.US\$4.5) per day increased revenue. Aker's (2008) work on West African grain traders shows similar results in increasing profitability by $29 \%$ per year. ${ }^{5}$ Katengeza et al (2014) report Malawian farmers gaining c.US\$90 additional income through participation in an ICT-based market information service. Overall, data concurs with Chew et al (2011: 11) that there is a "small, albeit statistically significant, relationship between total ICT access and [microenterprise] growth". ${ }^{6}$

ICT Sector: ICTs can also help by creating a new employment-related income. A wellknown example here is that of the Grameen "Phone Ladies" who earned an income averaging around US\$300 per year from acting as a mobile phone call salesperson; an average $24 \%$ of their household's total income (Richardson et al 2000) ${ }^{7}$. Other evidence drawn from an impact sourcing ${ }^{8}$ initiative in Kerala that created IT jobs for unemployed women from below-poverty-line families suggested they earned an average US\$540 per year, representing $43 \%$ of total household income (Heeks \& Arun 2010).

of that money: remittances are mainly spent on consumption, and it seems that a significant amount of money transferred as airtime is then used as airtime (Walia \& Goodman 2007; Duncombe 2012).

${ }^{4}$ As with remittances, it is unclear if this provides an additional income that would not otherwise be received, or if it merely substitutes one financial channel for another.

${ }^{5}$ The timing of these studies is notable, with results potentially arising from arbitrage opportunities available to some (e.g. intermediaries who had phones) and not others (e.g. producers and consumers who lacked them). Subsequent studies on Keralan fish and West African grain have shown differing results often contingent on contextual variables (Aker \& Fafchamps 2013, Srinivasan \& Burrell 2013).

${ }^{6}$ This is certainly a widespread perception, with surveys showing a great majority of entrepreneurs say use of ICTs (mobile phones) had led to an increase in income and profits for reasons including less travel, cheaper communications, wider customer and supplier networks, and better service: $75 \%$ of East Africa female entrepreneurs (Komunte et al 2012), 90\% of smallholder farmers in Lebanon (Hamade 2012), and 91\% of micro-entrepreneurs in Kenya (Mwangi \& Acosta 2013).

${ }^{7}$ By contrast, profits increased by just $9 \%$ for the Keralan fishermen and, given undoubted additional sources of income in their households, the income increase will be less. Data from Sivasubramaniam (1991) indicates 75\% of income in South Indian fishing households comes from fishing, suggesting ICT use by fishermen might produce about a $7 \%$ increase in household income. At least in these instances, then, ICT Sector application of ICTs has a much more significant poverty eradication effect than Enterprise ICT Use.

8 "Impact sourcing" (also called "social outsourcing") means the targeting of IT outsourcing contracts to marginalised groups; with an explicit aim of poverty eradication and achievement of other socioeconomic development objectives (Heeks 2013). 
Judging the size of new employment generated by ICTs - particularly for those who would otherwise be classified as below-poverty-line - is not that easy ${ }^{9}$. One overall sense of job creation comes from Pakistan, where the telecommunications sector is responsible for creation of an estimated 1.4 million jobs (UNCTAD 2010) ${ }^{10}$ and from India where an estimated 2.8 million people were employed directly or indirectly in the mobile sector and a further 7 million in induced employment (World Bank 2012). Similarly, the GSMA (2013) estimates around 3.3 million direct and indirect jobs created by the mobile sector in Africa. ${ }^{11}$

\section{Box 1. The Other Side of the Coin: ICT Costs and Inequality}

So far, the focus has been on the positive impacts that ICT can have on the lives of the poor. However, it must be recognised that there are other impacts associated with the technology. Important impacts within the socio-cultural realm, such as exacerbation of intra-household tensions and incidents of domestic violence (Wakunuma 2007), are not discussed here. Instead, the focus will be on the financial and economic.

The direct and obvious such impact is the financial cost of ICTs for the poor. There appears to be relatively little evidence to date on Internet/PC-related expenditure but we do know (e.g. James 2013, Sey et al 2013) that ownership of these is not possible for the poor; diffusion and use in poor communities is still relatively limited (the Internet user figures cited above lie largely outside these communities); many telecentre initiatives provide free or subsided-cost access; and a leitmotif of research on public access ICT venues is first the limited accessibility to those on lowest incomes ("generally users are of middle-income backgrounds" and "these venues do not serve the very poor" (ibid.: 79)) and second, the problem of financial sustainability due to lack of expenditure by poor communities. A survey across Africa in 2011/12 - taking a cross-section of households rather than a specific focus on poor communities - found less than $6 \%$ of those households had Internet access and less than $16 \%$ were Internet users (including mobile and public Internet usage) (Stork et al 2013). Given the known skews in Internet access and use by income, this means Internet costs for the lowest income quartile will be close to zero because usage will be close zero (Norris \& Inglehart 2013, Pearce \& Rice 2013).

\footnotetext{
${ }^{9}$ All the figures provided next are based on some fairly heroic extrapolations; often including multiplier estimates of informal: formal employment given formal employment numbers are known but informal numbers not (data from Deloitte underpinning the figures shown here indicated multipliers that vary from 25:1 to 100:1. Definitions are as follows: direct employment means formal jobs with telecom operators; indirect means those working in telecommunications but outside the main operators such as those in distribution, repair and retail including SIM and airtime and top-up card retailers; induced means the broader employment impact of efficiencies and GDP growth including those who work for people in direct and indirect employment.

${ }^{10}$ Only 12,000 of these are directly employed by mobile operators. 270,000 are classified as indirect mobile jobs (installation, retail, repair); and 450,000 are listed as being induced by mobile telephony. Of the others, 480,000 are employed in relation to payphones, and 120,000 work in long-distance telephony.

${ }^{11} 119,000$ in infrastructure and support; 124,000 with network operators; 2.54 million in distribution and retail; and 509,000 in content and services.
} 
Much more has been reported on the cost of telephony; particularly mobile telephony. The amount spent is much higher than anticipated given historical figures from pre-mobile days. World Bank data from the late 1990s reported poorest groups would use up to $3.5 \%$ of expenditure on telecommunications (Forestier et al 2002). But later research has shown this to be far exceeded: for example, a survey in six Asian countries found the poorest quintile spending an unweighted average of $34.7 \%$ of personal income on mobile services alone (Aguero et al 2011); and research in Africa showed the bulk of the population (excluding the richest quartile) spending $11-27 \%$ of their monthly income on mobile; representing $30-74 \%$ of monthly disposable income (Gillwald \& Stork 2008). Not surprisingly, there is thus evidence that around one-fifth to one-quarter of individuals and households divert expenditure from other items - typically either food (e.g. meals foregone) or clothing - to mobiles (Chepken \& Muhalia 2010, iHub Research 2012, Duncan 2013).

\section{ICTs and Inequality}

These expenditure figures do reflect the value of mobile telecommunications to poor users. But such users also face a high cost of telecommunications; a cost premium for poor users compared to richer users mainly due to their use of pre-paid tariffs (Barrantes \& Galperin 2008). The poor are thus paying more in absolute terms. And, of course, they are paying more in relative terms. Compared to the $34.7 \%$ figure given above, the richest quintile in Asia spend only $4.4 \%$ of income on mobile (Aguero et al 2011), and compared to the 11-27\% figure, the richest quartile in Africa spend only $5-8 \%$ of income on mobile (Gillwald \& Stork 2008). Within the OECD, by comparison, average expenditure on all telecommunications was just $2.7 \%$ of income (OECD 2013). ${ }^{12}$

On the expenditure side, then, there is evidence that ICTs are technologies of inequality; imposing greater costs on the poor than on the rich. The much more difficult question is whether the benefit side of the equation compensates. Prima facie, it is difficult to see why ICTs should bring more benefits to the poor than they do to the rich given, for example, the greater difficulties in delivering "information impact chain" resources required to allow ICTs to deliver development outcomes (see Box 2 and Heeks \& Kanashiro 2009a, Forestier et al 2002). The high proportion of income spent on ICTs - mobile particularly - and the evidence of other spending foregone could suggest ICT-derived expenditure exceeds ICT-derived income.

Looking at financial benefits, the poor themselves seem to see problems. $25 \%$ of those surveyed in Sri Lanka had concerns about negative cost-benefit balance of mobile ownership; $75 \%$ of mobile owners surveyed in rural Tanzania felt costs exceeded benefits (de Silva et al 2008; Mpogole et al 2008). But this is hardly surprising given the likely interpretation by survey respondents of "benefits" in a cost-benefit question as relating to income generation. Ask the average OECD

\footnotetext{
${ }^{12}$ Similar patterns of inequality can be seen in specific relation to the costs of broadband (e.g. A4AI 2013).
} 
household if they earn more money from their telephone than they spend and they would look at you in bemusement. Just as in poor communities of the global South, the phone is used much more for social (including emergency) purposes than economic purposes (Duncombe 2012, Rahman et al 2013), with social development uses of other ICTs also dominating over income-generating uses (Sey et al 2013).

Looking more specifically at income-generating uses of ICTs, at least four - already described - can be identified. Two fall particularly under the "Other ICT Uses" heading: first, cost savings and possible income gained due to journeys foregone; second, use of ICTs - especially mobile phones - for financial purposes by poor consumers; for example, as described above, they can facilitate an inflow of remittance money (from social contacts; showing the porosity of any notional social:economic division of use). Third, there will be use of ICTs by existing enterprises to increase income, relating particularly to use of enterprise-related information dealing with supply, process, and sales.

Finally, there is the use of digital technologies to create new ICT sector jobs. Yet again, the evidence is that a very large pool of livelihoods has been created via ICTs: some $70 \%$ of the telecommunications-related jobs created in Pakistan - around 900,000 in total - were payphone operators and airtime retailers of the type found in poor communities (UNCTAD 2010). Other studies report significant numbers of livelihoods, especially related to mobile, being created in low-income communities. $41 \%$ of a convenience sample in rural areas of Nigeria made money from offering public mobile phone call services, selling recharge cards sent from urban relatives, or charging mobile phone batteries (Baro \& Endouware 2013); and there are similar reports of the density of ICT-related livelihoods in low-income urban areas (e.g. Rangaswamy \& Nair 2012; Foster 2013).

It is impossible to gauge whether these benefit streams will be greater for the rich than the poor. ICT-enabled remittances may be progressive financial flows from (in relative terms) rich to poor, but the non-poor will also use ICTs - likely more effectively - to produce income in their enterprises; and they will be the recipients of almost all formal ICT sector jobs. Jumping from the micro to the macro, this tendency of the rich to benefit from ICTs more than the poor has certainly been the case at the level of nations (Heeks \& Kenny 2002).

\section{Cost-Benefit Analysis}

Finally, can one get any sense of overall economic costs and benefits of ICTs for the poor? Looking at the types of use identified, it seems likely that under the "Other ICT Uses" heading, ICTs are economically more cost than benefit; as noted, this is to be expected since ICTs act here mainly like a consumption good akin to a radio or furniture, delivering non-economic rather than economic benefits (to the extent that one can separate these). In the "ICT Sector" category, the balance is almost all economic benefit: ICT sector workers are gaining wages; ICT sector entrepreneurs are gaining income and hopefully some profit. In the "Enterprise ICT Uses" category, economic cost-benefit data is slim but it does exist. Jensen (2007), for example, 
shows Keralan fishermen using mobile phones to gain Rs.205 per day in increased revenue, but paying Rs.72 per day in mobile costs; a net gain of Rs.133 (c.US\$3) per day. ${ }^{13}$

Even slimmer is the data on cost-benefit for those who do not own ICTs. To understand this, a nuanced model of the digital divide is required (see Figure 2), dividing poor citizens into one of four camps.

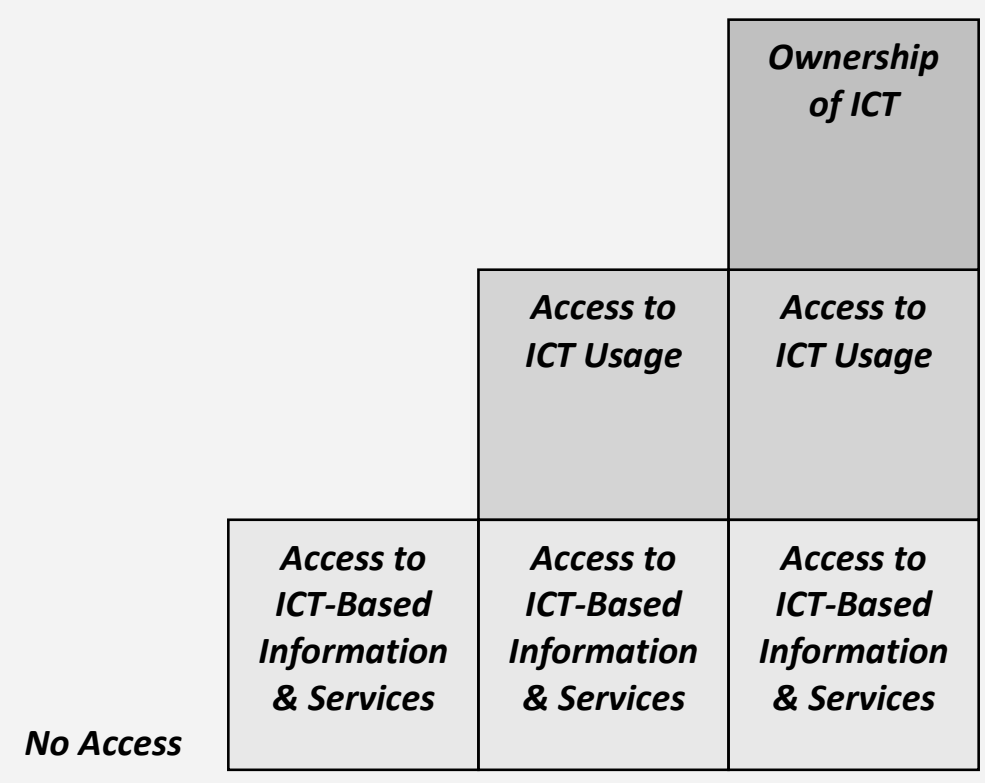

Figure 2: Categories of Digital Divide

Those without any access are truly on the wrong side of the digital divide. They have no ICT costs but evidence about benefits is mixed. Some find they have no benefits, which are only gained by those with access. For example, micro-producers in Nigeria without mobile phones found they were losing orders - and, hence, income - to those who had mobile phones (Jagun et al 2008).

On the other hand, there is sometimes evidence of a "digital provide": a general increase in welfare from the presence of ICTs within a community even for those with no access. This was seen through two rather less-publicised outcomes from the case of the Keralan fishermen using mobile phones to check market prices, noted above (Jensen 2007). Those fishermen without mobile phones also saw their profit rise by an average Rs.97 (c.US\$2) per day as a result of the general improvements in market efficiency which phones introduced. This was about half the profit increase seen by phone owners and meant, even allowing for the additional costs, that returns to phone ownership were greater than those for non-ownership. In addition, the revenue gains by all fishermen arose because they wasted less (i.e. sold more) of the fish they caught. But the actual price per kg for fish decreased due to the increase in supply arising from less waste. This delivered a second digital provide

\footnotetext{
${ }^{13}$ This excludes the cost of the phone though, as Jensen (2007) points out, additional profits would cover that cost in less than two months.
} 
benefit: fish consumers now paid less than previously thanks to the mobile-induced efficiency gains.

There is also evidence of those in the second and third digital divide categories gaining from a digital provide. For example, farmers in the third category in Northern Ghana were able to borrow mobile phones from neighbours and gather agricultural guidance information, or market price information (Smith 2010). Even those who did not themselves use the phone benefited from information passed on from phone owners, including more frequent meetings with agricultural extension officers; meetings that were coordinated by phone owners. Phone owners benefited more, so the overall conclusion - as with the fishermen, and forgiving the pun - is that ICTs are a rising tide that lifts all boats, but with the boats of ICT owners (typically the richer members of the community) being lifted further.

\section{Conclusion}

The limited research base means conclusions must come with caveats. It is possible that ICTs bring to the poor economic costs that exceed their benefits; but the opposite is also possible. However, even if economic benefits do exceed costs for the poor, the costs are greater and benefits are lower than for rich users. It is therefore possible that ICTs simultaneously help reduce absolute poverty levels but increase overall income inequalities.

\section{C2. Livelihoods: Poverty Eradication as Asset Accumulation}

If those in poor communities are asked about their own definition of development and their own goals, they go well beyond the economic to encompass social and political issues (Kivunike et al 2011). Likewise, the understanding of "poverty" has expanded to recognise that poverty is not just a financial issue; this particularly occurring in the development of the livelihoods approach. The livelihoods approach recognises not just the ultra-financial nature of poverty but also the importance of context: see Figure 3 (DFID 1999). 


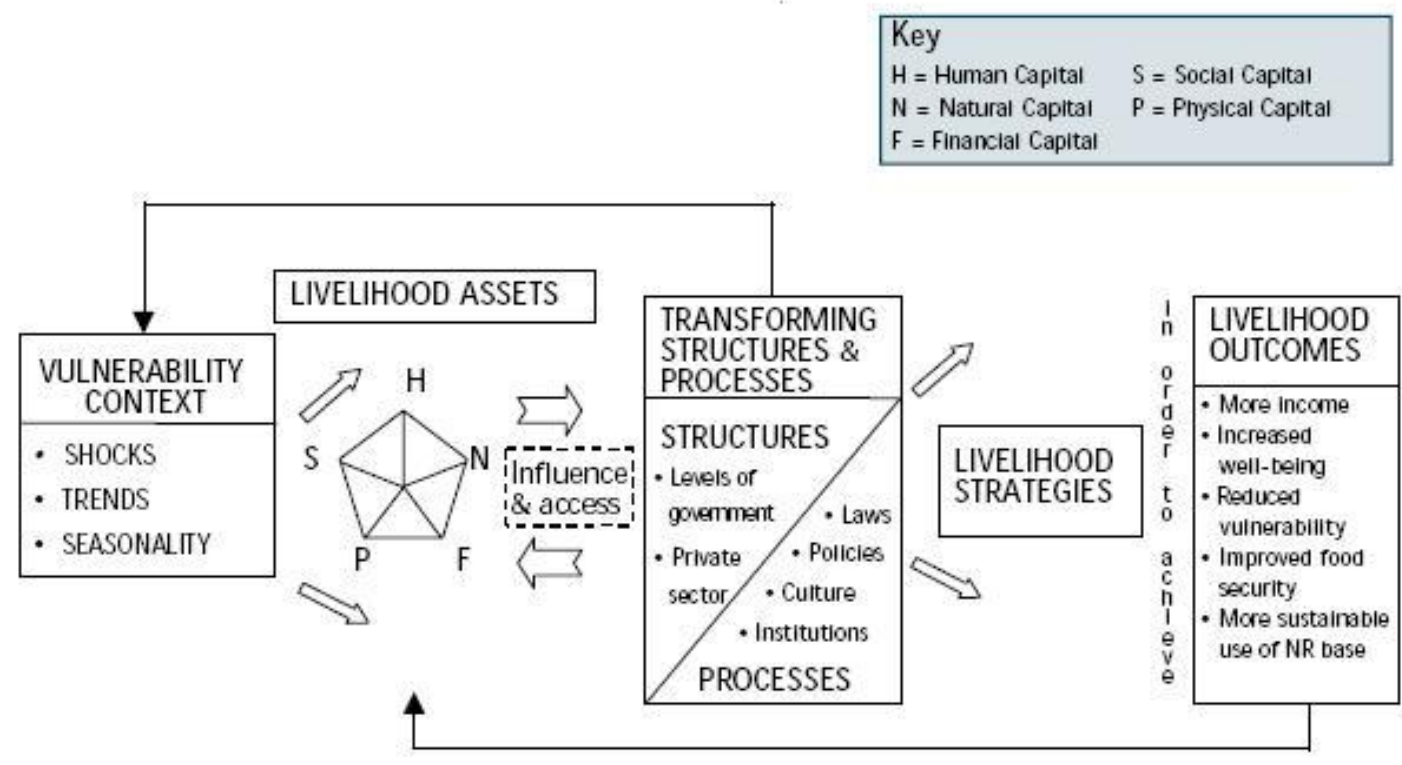

Figure 3: The Livelihoods Framework

Work using this perspective has tended to treat context and structures/processes as factors impacting ICT usage, rather than vice versa (Heeks \& Molla 2009). Where ICT impact is measured, it is largely in terms of livelihood strategies, and unfortunately livelihood outcomes seem rarely considered except, sometimes, in terms of ICT impact on the assets pentagon. Here only these latter impacts will be considered, leaving the question of impact on strategies - what people are able to do - for discussion below. As before, impacts are divided into the three usage categories. Given that financial capital is part of the assets pentagon, the findings from Section C1 still apply, and the focus here will be particularly on the accumulation of other assets which help contribute both towards eradication of poverty in its broader sense (asset deprivation) and towards more effective livelihood strategies:

Other ICT Uses: information delivery would be a main benefit such as information on health reminding patients to take medication, or ICT use to enable greater interaction with health professionals, which strengthens human capital (e.g. Hamade 2012, Denkinger et al 2013). Although more generally seen just as the precursor to enaction of new livelihood strategies, the intensive interaction with technology during an IT training course can itself create a livelihoods impact for excluded groups (Khan \& Ghadially 2010). This is seen not just in the formation of skills (human capital), but also in empowerment (political capital); instilling a belief that many more things are now possible; with that belief having been shown to enable new livelihood strategies.

Enterprise ICT Use: the type of informal sector entrepreneur that is typical of poor communities relies heavily on social capital, with no clear divide between business and social relations - family, friends, neighbours and others may fall into both categories. Through not just receipt of information but also ICT-based interaction 
and transaction, poor entrepreneurs can build their social capital (and so, in turn, improve their livelihoods). The major reported impact of ICTs and social capital is intensification of existing socio-economic relations - for example using mobile phone calls or email messages to strengthen existing ties. This has been found among urban micro-entrepreneurs (e.g. Donner 2007, Makoza \& Chigona 2012) and farmers (Martin \& Abbott 2011). However, there is also some evidence that - more valuably - ICTs can play a role in building new socio-economic relations, allowing entrepreneurs to seek out new contacts by phone or Web search, and allowing them to capture contact details of any new person met face-to-face (Burrell \& Matovu 2009, llavarasan \& Levy 2012). They thus extend their social capital.

ICT Sector: where ICTs are used to create a new ICT sector livelihood, this has an effect on asset accumulation well beyond just the financial. For example, women in the Kerala IT impact sourcing initiative cited above (Heeks \& Arun 2010) saw gains in all livelihood assets: all reported new technical and entrepreneurial skills (human capital); $90 \%$ had invested in physical capital such as gold, housing and equipment; $96 \%$ could demonstrate improved social capital in relation to business, community and/or institutional linkages; all reported a growth in self-confidence, and two-thirds reported greater respect, recognition and acceptance in their families and communities (political capital/empowerment). ${ }^{14}$ Evidence of asset accumulation from other forms of ICT sector activity in low-income communities can also be found such as human and social capital formation (Rangaswamy \& Nair 2012).

\section{Box 2. Factors Affecting ICTs' Poverty Impact: The Information Impact Chain}

In most of the roles described for poverty eradication - at least outside the ICT sector-ICTs just process and communicate information. But more than this is required in order to create development impacts even once the barriers of ICT access have been overcome. ICT-delivered medication reminder information is of no use if the recipient cannot access or afford the relevant medicine. ICT-delivered information about new social contacts is of no use if the recipient lacks the confidence to utilise those contacts.

The information impact chain (Heeks \& Kanashiro 2009a \& 2009b) is a reminder that more than just ICT is needed to create development results. Relevant, appropriately-presented data must be available. Recipients must have the skills, knowledge, money and motivation to access that data; to assess its qualities; and to apply it to their particular needs. To actually deliver results, action resources are needed: money and raw materials; skills to undertake the action; power and motivation to make it happen; social and business contacts to create the desired result. To impact development, a raft of complementary resources - in livelihoods terms, a set of complementary assets - must be present. Figure 4 categorises these in terms of the links in the chain as data, information, and action resources.

\footnotetext{
${ }^{14}$ For further evidence on asset-based and other benefits of impact sourcing, see Madon \& Sharanappa (2013), and Malik et al (2013).
} 


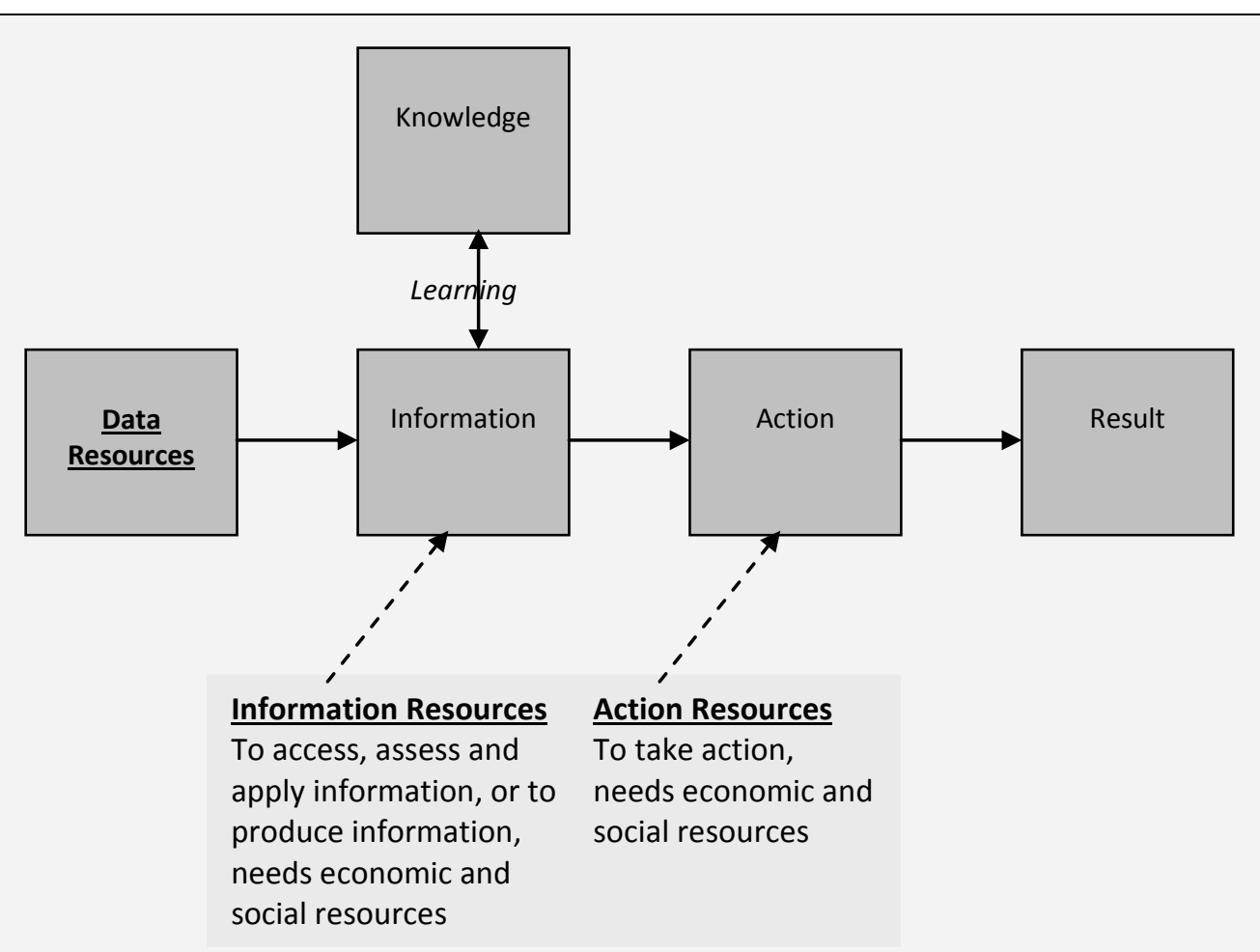

Figure 4: The Information Impact Chain

The chain helps to explain, for example, why the mobile Internet is currently of limited value in poverty eradication. Surveys of low-income groups in Asia and Africa show key information chain resources to be absent despite the technology's potential (Zainudeen \& Ratnadiwakara 2011, Calandro \& Wang 2012, Stork et al 2013). These included a lack of awareness of mobile Internet, a lack of money to afford access, a lack of relevant ICT skills, and a lack of motivation to enact some possible applications.

The chain also helps to explain some of the sustainability problems that some ICT projects have faced (Harris 2004. Pade-Khene et al 2011). For example, projects targeting poverty eradication have seen key information chain resources such as money, skills and motivation provided only temporarily by an external agency, leading to a sustainability failure when those resources are removed.

\section{C3. Capabilities: Poverty Eradication as Greater Role Freedom}

Taking one further step away from the idea of poverty as being just about money, it can be understood in the sense of poverty of opportunity: the lack of abilities and chances to do what is necessary to progress in life. Money will be one part of this. There are also links to livelihoods ideas such as the assets one has, the context one is in, and the strategies one is able to adopt. 
These ideas were best encapsulated by Amartya Sen in the capabilities approach, which sees development as the expansion of individual freedoms: "what the person is free to do and achieve in pursuit of whatever goals or values he or she regards as important" (Sen 1985: 203). What a person is free to do represents their capabilities; what they actually achieve represents their functionings (Figure 5). This is not just a theoretical notion. If asked, residents in poor communities can readily explain that what they seek from ICTs is greater opportunity; in particular a greater ability to undertake economic and social activities (Kivunike et al 2011).

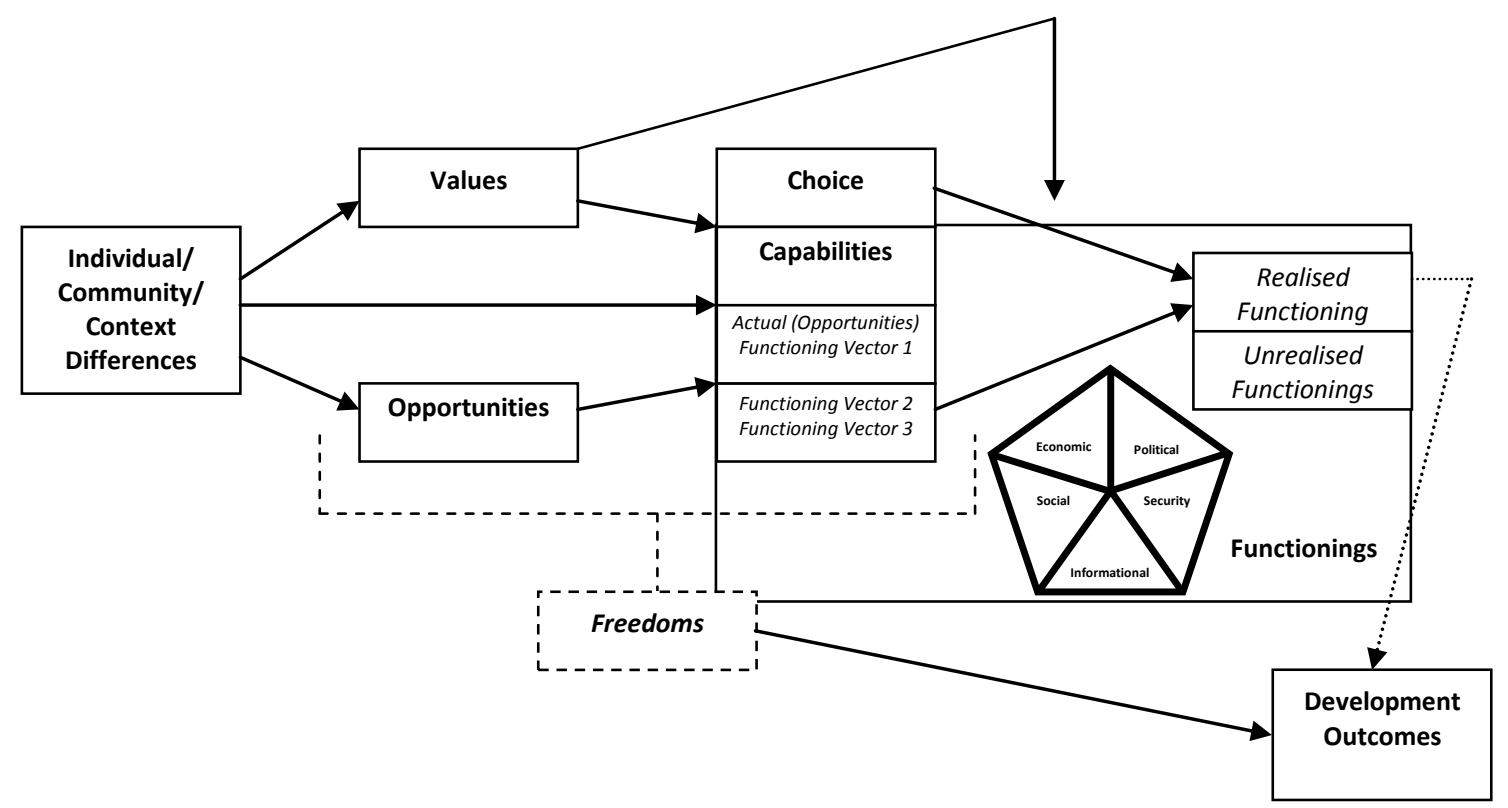

Figure 5: The Capabilities Framework

This understanding of development - of poverty eradication as an eradication of poverty of opportunities - can be seen as Sen intends it: as at once the broadest but also most fundamental view of development. Sen's idea of development as freedom, and of capabilities, goes beyond the more lay notion of capabilities - as skills and as knowledge. It takes a much broader view of what capabilities are, and in impact terms the interest is mainly in realised functionings. Put more simply, its main interest is therefore in what ICTs enable people to be and to do.

This can be encapsulated in the notion of the roles that people play through ICTs; a role being both who you are and what you do. Developing from the concept of roles within the workplace (e.g. Biddle 1986, Huvila 2008), we can define a role as a set of tasks and behaviours that are performed by an individual. Roles therefore represent something halfway between a realised functioning and a livelihood. They are shaped by "a mix of both social dynamics and technological affordances" (Postigo 2011: 184).

In this section, a set of roles will be analysed that the poor can play vis-à-vis ICT; represented as a ladder, as shown in Figure 6 . In simple terms, climbing the ladder could be read as a greater intensity of engagement with the technology. It is also a ladder of technological capability; each step reflecting higher-level competencies 
(skills, knowledge and perhaps also attitudes) that are required for this type of ICT use but which are also created by this type of ICT use. And it also represents Sen's ideas, with each successive role being a greater level of realised functioning; and hence one more step in the climb away from poverty.

Although the alignment is not exact, the various roles can be understood in relation to the categories of ICT use identified in Figure 1. These are summarised in Figure 6, and detailed below.

\section{Non-Use:}

In these roles, members of poor communities are not direct users of either the technology or the information and services it carries:

- Delinked: there is no obvious connection between particular ICT applications and poor communities. An example might be applications within a large corporation which does not produce goods or services of relevance to poor communities.

- Indirect: this represents a very large category of ICT applications in organisations in which the poor have no direct connection with the ICT, but in which the ICT application does deliver some benefit. Examples might include the use of ICTs to provide ethical and fair trade information which then drives better working terms and conditions to poorly-paid factory or farm workers (Heeks \& Duncombe 2004, Light 2010), and the use of ICTs in large firms to improve supply, distribution and marketing to base-of-the-pyramid markets (Subrahmanyan \& Gomez-Arias 2008, Chickweche \& Fletcher 2013).

\section{Other ICT Uses to Enterprise ICT Use:}

In these roles, the poor make direct use of either the technology or the information and services it carries. They can do this either as entrepreneurs or in other roles:

- Intermediated consumer: this can represent all three main levels of consumption-related use of ICTs - one-way broadcast of information, interaction, transaction - but in no case is the consumer a direct ICT user; hence there is limited ICT-enabled change in role. A typical example might be the delivery of e-government services in India (Bhatnagar \& Singh 2010). These services are undertaken at kiosks and service centres staffed by intermediaries. Evaluation shows that impacts vary quite significantly across projects but that they are relatively limited in terms of changing the consumer's pattern of functionings and opportunities. ${ }^{15}$

- Passive consumer: a role in which there is direct use of the ICTs but just to receive "broadcast" information e.g. about health (Kliner et al 2013) or market prices (Katengeza et al 2014). As noted in Box 2, this role can partly be seen as the starting point of an information impact chain which will only lead to development outcomes if fully enacted; that enaction requiring other resources and entailing a different role.

\footnotetext{
${ }^{15}$ Typical examples include: reduction in average waiting time (by about 50 minutes), improved perceptions of service quality (average 15\% increase in rating), and reductions in bribes (paid on average $6 \%$ of occasions as opposed to $16 \%$ pre-ICT).
} 
- Active user: digitally-enabled interaction and transaction with socio-economic contacts; for example, the remittance of "mobile money" from urban migrants to rural relatives (Duncombe 2012), or the use of telecentres by farmers to get agricultural guidance from distant advisers (Heeks \& Kanashiro 2009a), or use of mobiles by micro-entrepreneurs to contact customers (Donner \& Escobari 2010).

\section{Enterprise ICT Use to ICT Sector:}

In this role, those in poor communities make direct use of ICTs:

- Producer: creation of enduring digital content. This could be undertaken by an entrepreneur, for example, advertising goods and services on a voice-activated information service (Agarwal et al 2010). But it also overlaps into the ICT sector category; for example, musicians or video producers recording then sharing content on mobile phones (Impio et al 2008, Walton et al 2012).

\section{ICT Sector:}

In these roles, the use of ICTs is so central to the livelihood that it is seen as lying within the ICT sector:

- Worker: employment in an ICT-based activity (one that could not exist without ICTs); for example, those employed to undertake data entry and other digitisation tasks as part of IT impact sourcing contracts (Madon \& Sharanappa 2013) and rural BPO contracts (Knowledge@Wharton 2010). Though only indirectly connected to the technology, one might also include here entire new livelihoods that are directly attributable to the ICT sector, such as the ancillary staff who work in ICT enterprises (e.g. Lakshmi Ratan et al 2009). (More questionable still would be the inclusion of induced employment; for example, those who work as cooks, cleaners, etc. for households of those employed in the ICT sector.)

- Entrepreneur: creation of a self-employed ICT-based livelihood (one that could not exist without ICTs); for example, the umbrella people selling phone calls by the roadside (Neuwirth 2011, Baro \& Endouware 2013), or the PC kiosks providing digital photography, e-ticketing and e-government services (Rangaswamy \& Nair 2012).

- Innovator: adaptation of the technology by modifying the technology itself such as the "street hacks" that alter mobiles to accept dual SIMs (Chipchase 2009), or by modifying ICT-enabled processes such as the mobile money agents who adapt methods of service delivery to match their local context (Foster \& Heeks 2013). 


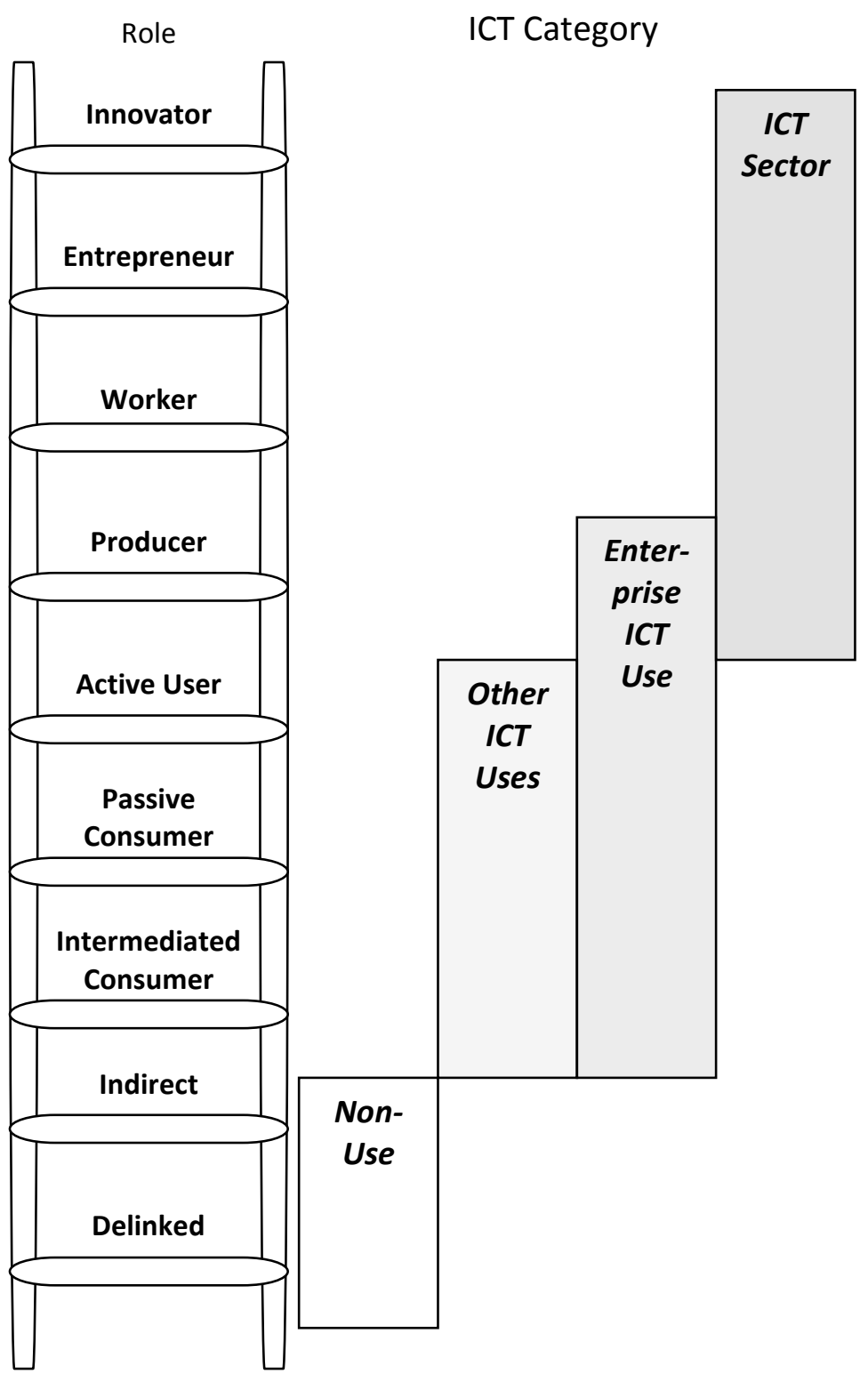

Figure 6: Ladder of ICT-Related Roles for the Poor

Some differentiation in terms of technology is likely. In a fast-moving field, there are always problems that any published data tends to be somewhat "behind the curve". But the picture painted so far during the 2010s is one in which the poor are struggling to reach even passive consumer status vis-à-vis Internet-connected PCs. Certainly, there are jobs, enterprises and innovations related to PCs and the Internet but they are not that extensive. For example, Agboma (2010) reports one-sixth of all registered enterprises in Benin City, Nigeria, were PC/Internet-related microenterprises (IT training, software, Internet service provider, cybercafé). If (and it's a very big if), that figure could be extrapolated, it would suggest 100,000 such enterprises across all of Africa. ${ }^{16}$ How many of these draw entrepreneurs and

\footnotetext{
${ }^{16}$ Agboma's figures show roughly one ICT enterprise registered per 10,000 population. Given the urban population of Africa is around 400 million (UNDESA 2012), this would suggest around 40,000 such enterprises being registered each year. Moving on from here is difficult (Heeks 2008). Most
} 
employees from poor communities is unclear but in Agboma's work most entrepreneurs, at least, were university graduates who were able to draw on family sources for investment capital.

By contrast, most of the higher-level role examples found were related to mobiles. All mobile users (who now form the majority of developing country populations) are at least passive users; and increasing numbers will be active users and even producers. The number of jobs created by the mobile sector is far greater than that for other parts of the ICT sector: as seen above, perhaps 2.8 million in India and 3.3 million in Africa. Evidence cited above suggests a significant proportion of these will be based in poor communities. At least on the basis of current evidence, then, it is the mobile phone rather than other digital technologies that is offering a route up the ladder and away from poverty.

enterprises are never registered, though this proportion seems to be lower in ICT than other fields. Very likely many enterprises which register never actually start up. Those that do will continue in operation alongside new registrations. But the "death rate" for micro-enterprises is also high. Adding all this together, a ballpark figure of 100,000 Internet/PC enterprises in Africa seems not unreasonable. 


\section{C4. Strengths and Weaknesses of Perspectives}

Some of the strengths and weaknesses of applying the three perspectives to assess ICT4D impact on poverty eradication can be summarised (see Table 1) (adapted from Heeks \& Molla 2009).

\begin{tabular}{|c|c|c|c|}
\hline & Economic & Livelihoods & Capabilities \\
\hline Strengths & $\begin{array}{l}\text { - Provides a simple, quantified and } \\
\text { relatively objective summary of ICT } \\
\text { impact. Analysis results are easy to } \\
\text { interpret and communicate. } \\
\text { Useful for evaluating the financial } \\
\text { performance and/or sustainability of } \\
\text { ICT4D initiatives. Particularly useful } \\
\text { for understanding enterprise-related } \\
\text { impacts of ICTs, and for understanding } \\
\text { development of markets and } \\
\text { commerce. Applicable from individual } \\
\text { micro-enterprises up to analysis of } \\
\text { macro-economic impact of ICTs. } \\
\text { Can be applied to different } \\
\text { technologies, markets and supply } \\
\text { chains. Generic indicators such as } \\
\text { price fluctuations can be adapted to } \\
\text { the specific context of evaluation. } \\
\text { Interpretation of indicators is mostly } \\
\text { straightforward. }\end{array}$ & $\begin{array}{l}\text { - Comprehensive coverage of poverty } \\
\text { eradication-related impacts (if using } \\
\text { all SL framework elements). } \\
\text { - Well-accepted and well-understood } \\
\text { by development community. } \\
\text { - Lot of guidance on general methods } \\
\text { and implementation (e.g. } \\
\text { www.livelihoods.org). } \\
\text { - Flexible to different situations } \\
\text { because considers specifics of each } \\
\text { different context, assets, institutions, } \\
\text { etc. } \\
\text { Covers the (often complex) realities of } \\
\text { people's lived experiences. } \\
\text { Avoids over-emphasis on the technical } \\
\text { given focus on broader social } \\
\text { structures and processes. } \\
\text { Allows a causal chain of impacts on } \\
\text { and impacts of ICT4D. }\end{array}$ & $\begin{array}{l}\text { - Provides an original, broad and } \\
\text { foundational perspective on ICTs' } \\
\text { relation to poverty eradication. } \\
\text { - } \quad \text { Recognises each individual person: } \\
\text { their aspirations, needs and choices. } \\
\text { - } \text { Avoids both social and technological } \\
\text { determinism: recognises that } \\
\text { technology can create new freedoms } \\
\text { but also explains why same } \\
\text { technology leads to different } \\
\text { outcomes in different situations. } \\
\text { Framework is well-recognised by } \\
\text { development agencies and } \\
\text { practitioners. } \\
\text { Useful focus on non-usage (unrealised } \\
\text { functionings) and on constraints to } \\
\text { action (unfreedoms). }\end{array}$ \\
\hline
\end{tabular}




\begin{tabular}{|c|c|c|c|}
\hline & Economic & Livelihoods & Capabilities \\
\hline Weaknesses & $\begin{array}{l}\text { - Mostly limited to financial (or } \\
\text { financialisable) income impact. } \\
\text { Generally fails to account for many } \\
\text { broader developmental impacts of } \\
\text { ICTs including social, political, } \\
\text { institutional and technological. } \\
\text { - Identifying cost and income items, } \\
\text { accurately quantifying them, and } \\
\text { directly attributing them to ICTs is } \\
\text { often difficult and sometimes } \\
\text { subjective. } \\
\text { - Given the need to follow particular } \\
\text { sectors/supply chains in depth, it may } \\
\text { be difficult (and certainly time- } \\
\text { consuming) to assess some ICT4D } \\
\text { initiatives if they have impacts in } \\
\text { several different sectors. } \\
\text { Although the types of impacts } \\
\text { included as costs and income can be } \\
\text { identified and estimated based on the } \\
\text { specific content and context of the } \\
\text { project, this does not readily lend } \\
\text { itself to participative evaluation } \\
\text { approaches. }\end{array}$ & $\begin{array}{l}\text { - Poor/limited linkage to information } \\
\text { and ICTs; can make attributing } \\
\text { causality difficult because framework } \\
\text { contains a multiplicity of potential } \\
\text { independent, dependent and } \\
\text { intervening variables. } \\
\text { - Focus is more on broader outcomes } \\
\text { and impacts rather than specific } \\
\text { causal outputs from an individual } \\
\text { ICT4D initiative, at least if moving } \\
\text { beyond just asset impact. } \\
\text { - Overall framework is complex so may } \\
\text { be costly and time-consuming to } \\
\text { implement and hard to conclude and } \\
\text { generalise from. } \\
\text { - High-level nature of framework } \\
\text { requires interpretation to apply for } \\
\text { any given project. } \\
\text { More of a framework within which } \\
\text { impact assessment methods can be } \\
\text { slotted than a specific impact } \\
\text { assessment method. }\end{array}$ & $\begin{array}{l}\text { - Limited usage of framework to date } \\
\text { for ICT4D initiatives, so no consistent } \\
\text { approach for impact assessment } \\
\text { (though Kleine } 2013 \text { presents one } \\
\text { particularly-relevant approach). } \\
\text { - Requires interpretation to apply for } \\
\text { ICTs: original framework says nothing } \\
\text { explicit and is quite "academic" and } \\
\text { flexible (i.e. unclear). } \\
\text { - Would typically require definition (e.g. } \\
\text { participative) of what aspects of } \\
\text { freedom and capabilities are valued; } \\
\text { i.e. rather than pre-determined ladder } \\
\text { of roles. } \\
\text { - Requires understanding of the } \\
\text { potential freedoms NOT chosen, as } \\
\text { well as the actual freedoms chosen. } \\
\text { Complexity that capabilities are both } \\
\text { inputs to and outputs from any ICT4D } \\
\text { initiative. }\end{array}$ \\
\hline
\end{tabular}

Table 1: Summary of Strengths and Weaknesses of Evaluation of ICT Impact on Poverty Eradication from Different Perspectives 


\section{Summary and Implications}

Table 2 summarises some of the impacts on poverty of ICT usage. This summary oversimplifies and exaggerates differences; particularly between "Other ICT Uses" and "Enterprise ICT Uses", categories which overlap. However, there is some sense in moving down the table, that impact becomes more fundamental as it encompasses a broader and deeper view of the meaning and causes of poverty. Moving across the table, that impact probably touches fewer people but has a more substantial impact on those whom it touches.

\begin{tabular}{|l|l|l|l|}
\hline Economic & Other ICT Uses & Enterprise ICT Use & ICT Sector \\
\hline Livelihoods & $\begin{array}{l}\text { ICT-enabled journey } \\
\text { substitution }\end{array}$ & $\begin{array}{l}\text { ICT-enabled income } \\
\text { from market } \\
\text { information }\end{array}$ & $\begin{array}{l}\text { ICT-based } \\
\text { employment income }\end{array}$ \\
\hline Capabilities & Health information & $\begin{array}{l}\text { ICT-enabled } \\
\text { customer networks }\end{array}$ & $\begin{array}{l}\text { ICT-based } \\
\text { employment assets }\end{array}$ \\
\hline
\end{tabular}

Table 2: Summary Framework and Examples of ICT Impacts on Poverty

In sum, there has been evidence that suggests a greater depth of effect on poverty in moving from top-left to bottom-right but a narrower breadth in terms of numbers affected. (Though see also Box 3 for a discussion of potentially even-deeper development impacts.) A comparison of the extremes, at least, would seem to bear this out. Almost all mobile phone users within poor communities - hundreds of millions of people - will benefit from occasional journey substitution but the poverty eradication impact will be limited in value. By contrast, ICT innovators are creating a complete new livelihood and new role for themselves that can radically alter their poverty status. But their numbers will be relatively few - a small sub-set of the hundreds of thousands within poor communities who fall within the boundaries of the ICT sector.

It's rather a stretch but, on the basis of the limited quantitative evidence we have, perhaps we can propose something like a "95:5 rule". Typical consumption-related uses of ICTs (journey substitution, health, market information) touch $95 \%$ of people but make only a $5 \%$ difference to their livelihoods. Typical production-related uses of ICTs (the new jobs created in the ICT sector) touch $5 \%$ of people but make a $95 \%$ difference to their livelihood.

So some support is provided for the question posed in Figure 1, in which case the idea of greater depth of effect but narrower breadth of effect could be summarised graphically as a reverse pyramid, as shown in Figure 7. 


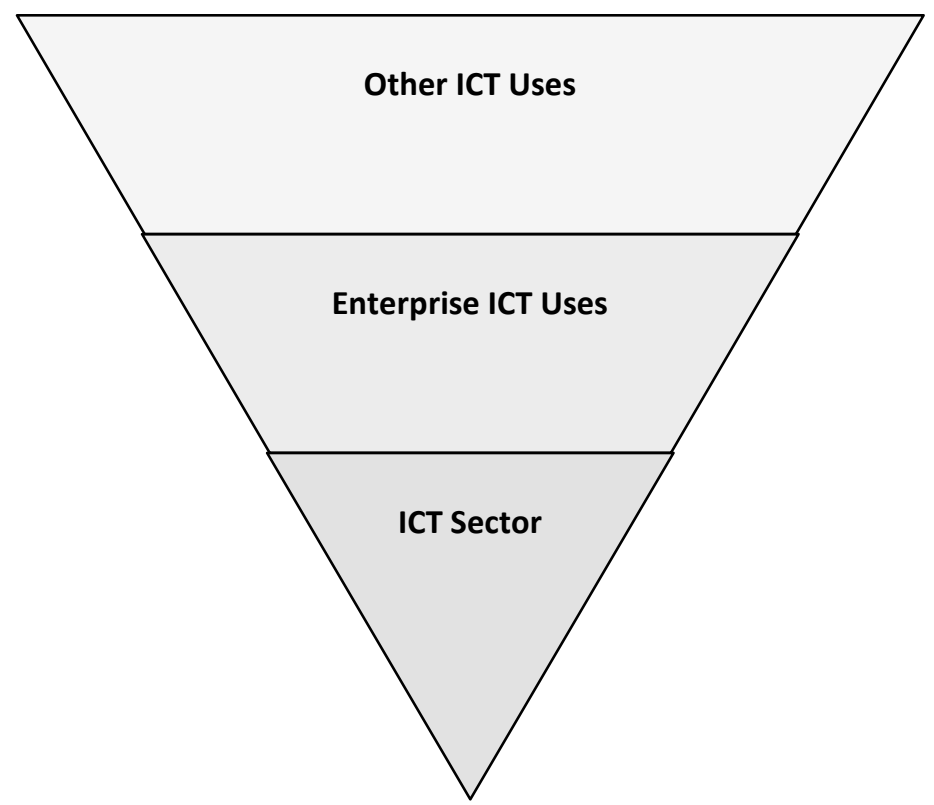

Figure 7: Poverty Eradication Impacts of ICTs

\section{Box 3. Progressive vs. Transformational Impact}

In development terms, two types of ICT application can be distinguished: progressive and transformational (e.g. Avgerou 2009). Progressive applications are those which could deliver substantial impacts - e.g. the creation of a new livelihood through ICT - but which do not change the underlying mechanisms and structures of development. Transformational applications make a more fundamental change. They may introduce an entirely new business model. They may alter the existing balance of power. This is per se of interest but also because of the increased emphasis on transformation in the post-2015 development agenda (Heeks 2014b).

The great majority of cases and applications reported here are progressive. That is not to denigrate them, but to recognise that they do not fulfil the promise of ICT that it would be a disruptive technology; that it might "change the rules of the game" and deliver "Development 2.0". There are some initial signs of Development 2.0: ICTs are enabling corrupt and inefficient "gatekeepers" to be disintermediated out of the development process; impact sourcing is a new business model enabled by ICTs; innovation has always taken place within poor communities but ICTs may help to genuinely empower grassroots innovation (Heeks 2010).

Such signs are only just emerging, but they mean the possibility does exist for ICTs to have a transformational impact on development - as it is starting to have on some business sectors in the global North such as music and other media.

In terms of policy-related recommendations, the explosion of ICT usage has not been matched by an explosion of ICT-for-development knowledge. Far more needs to be understood about the emerging new roles of ICTs in poor communities; and the emerging new impacts. 
Even so, some interim conclusions can be drawn. It is the mobile phone which has had by far the greatest impact on the lives of the poor. This is not simply an issue of rapid diffusion; but it relates to the ready appropriation of the technology by poor consumers (which also helps explain the diffusion). This has largely been a localisation of usage but also of application and maintenance and even, in some situations, of creation. As already noted, and put in terms of Figure 6 (i.e. roles, opportunities and capabilities), the mobile phone seems to have been able to push further up the ladder than other digital technologies.

Why does this occur? One answer is that the mobile phone imposes few "design-reality" gaps: see Figure 8 (Bass \& Heeks 2011). The requirements and assumptions built into this technology's design match relatively well to the realities of poor communities: it communicates the type of information in theory that is actually found in such communities in practice; the skills it requires for use are readily found in such communities; it imposes few "foreign" values; and so on.
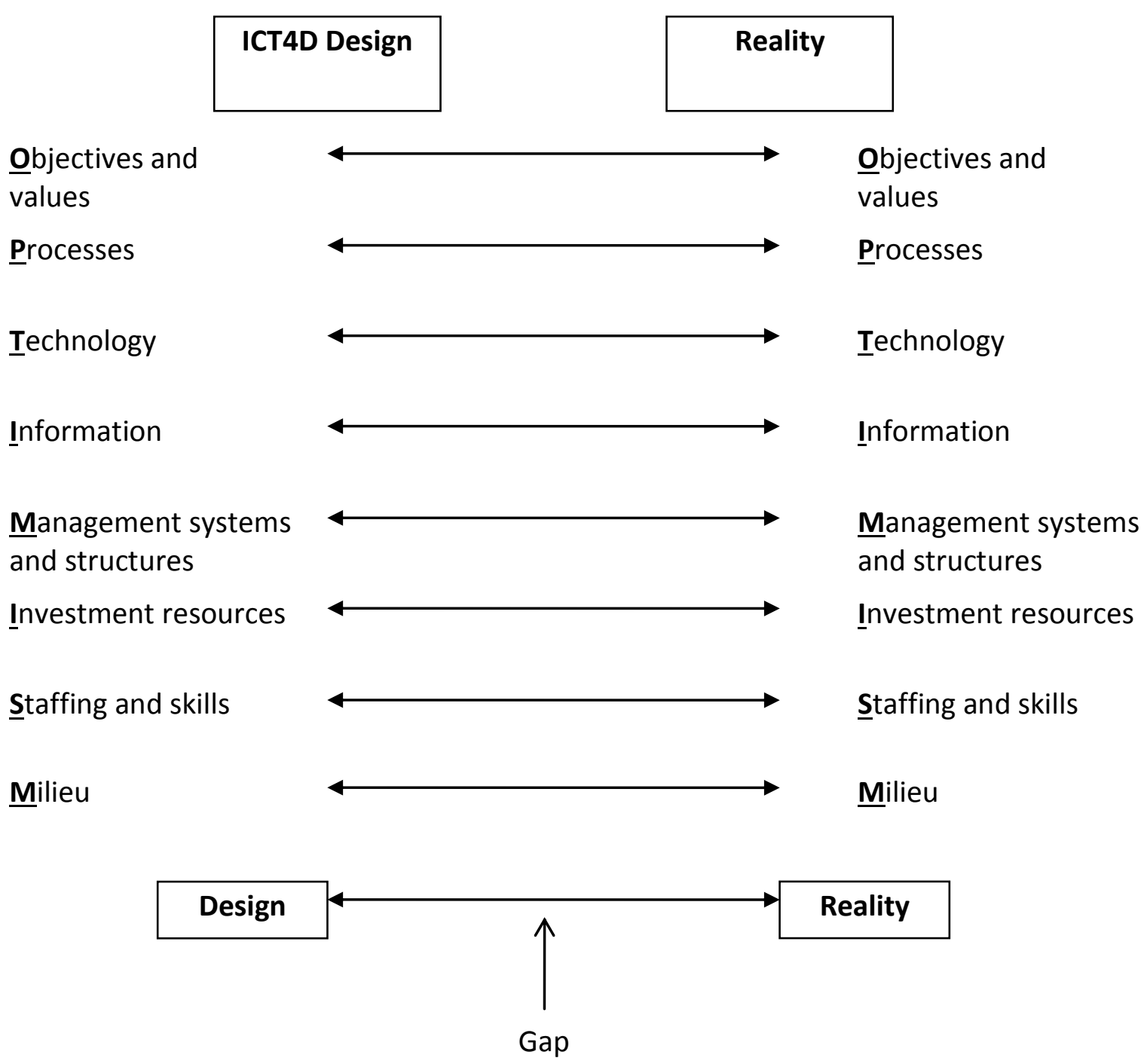

Figure 8: Design-Reality Gap Conceptual Framework 
This has two policy implications that are understood well from other technologies (ResIST 2009).

First, that a new "inclusive innovation" approach to ICTs (Heeks et al 2013) is required that not merely allows for, but actively supports, two types of innovation in addition to the traditional top-down R\&D model (Heeks 2009b):

- Collaborative ("para-poor") innovation is that done working alongside poor communities. This will enable the designs of ICT systems that are developed outside these communities to be adapted in ways that are appropriate; thus increasing their effective contribution to development. The assistance required will come, for example, in building knowledge about good practice in collaborative innovation; perhaps in subsidising such collaboration where market signals are ineffective.

- Grassroots ("per-poor") innovation is innovation by and within poor communities. Given the foundation of such innovations within these communities, their designs are already likely to be appropriate. The assistance here will come partly from enabling such innovations; for instance by building innovation capacity within communities. But it will also come from a "harvesting" system that can systematically scan for such innovations, and then provide a mechanism to share and scale them when identified (a model already in practice for other technologies, for example, via the Honey Bee Network). These ideas represent a move to change the design of ICT in order that it should better match the realities of poor communities.

Second, there need to be means to change those realities so that they match closer to ICT design expectations. This is likely to require action on all of the "OPTIMISM" dimensions indicated in Figure 8. For example, rolling out the electricity and telecommunications infrastructure to fill in the current "blank areas on the map". Vigorously developing ICT skills at the base of the pyramid. Changing attitudes, for example through demonstrator projects or the support of community exemplars. Increasing the availability of microfinance schemes. And so on. In some cases, "design expectations" will include the presence of the information impact chain resources that are required to turn ICT-based data into poverty eradication results. And, as also noted in Box 2, projects need to ensure that these resource realities are not just present temporarily, but sustainably.

By doing both of these - changing ICT designs to match closer to poor community realities, and changing poor community realities to match closer to ICT designs - there will be greater opportunities for ICTs to be a technology of poverty eradication rather than a technology of inequality. This will allow for appropriation, even innovation, of the technology within poor communities. This, in turn, will allow poor individuals to move further up the ICT role ladder, and thus capture more of the gains from the "digital revolution".

\section{Acknowledgements}

Acknowledgement is given to the financial support of UNCTAD in enabling production of the first draft of this paper, and in provision of guidance for its revision; and to Torbjörn Fredriksson of UNCTAD for helping shape the initial content. 


\section{References}

A4Al (2013) The Affordability Report 2013, Alliance for Affordable Internet, London, UK http://a4ai.org/wp-content/uploads/2013/12/Affordability-Report-2013-FINAL.pdf

Addison, T., Hulme, D. \& Kanbur, R. (2008) Poverty Dynamics: Measurement and Understanding from an Interdisciplinary Perspective, BWPI Working Paper 19, Brooks World Poverty Institute, University of Manchester, UK http://www.bwpi.manchester.ac.uk/resources/Working-Papers/bwpi-wp-1908.pdf

Agarwal, S.K., Kumar, A., Nanavati, A.A. \& Rajput, N. (2010) User-generated content creation and dissemination in rural areas, Information Technologies and International Development, $6(2), 21-37$

Agboma, F. (2010) A Multi-Level Assessment of Entrepreneurship in the Nigerian IT Sector, PhD thesis submission, Institute for Development Policy and Management, University of Manchester, UK

Agola, N.O. \& Awange, J.I. (2014) Globalized Poverty and Environment, Springer, Heidelberg

Aguero, A., de Silva, H. \& Kang, J. (2011) Bottom of the pyramid expenditure patterns on mobile services in selected emerging Asian countries, Information Technologies and International Development, 7(3), 19-32

Aker, J.C. (2008) Does Digital Divide or Provide? The Impact of Cell Phones on Grain Markets in Niger, BREAD Working Papers (177), Bureau for Research and Economic Analysis of Development, Duke University, Durham, NC http://ipl.econ.duke.edu/bread/papers/working/177.pdf

Aker, J.C. \& Fafchamps, M. (2013) Mobile Phone Coverage and Producer Markets: Evidence from West Africa, Discussion Paper 9491, Centre for Economic Policy Research, London, UK

Alzouma, G. (2013) Dimensions of the mobile divide in Niger, in: The Digital Divide, M. Ragnedda \& G.W. Muschert (eds), Routledge, Abingdon, UK, 297-208

Avgerou, C. (2009) Discourses on innovation and development in information systems in developing countries research, in: Assessing the Contribution of ICT to Development Goals, E. Byrne, B. Nicholson \& F. Salem (eds), Dubai School of Government, UAE, 1-21 http://ifip.dsg.ae/

Baro, E.E. \& Endouware, B.C. (2013) The effects of mobile phone on the socio-economic life of the rural dweller in the Niger Delta Region of Nigeria, Information Technology for Development, 19(3), 249-263

Barrantes, R. \& Galperin, H. (2008) Can the poor afford mobile telephony?, Telecommunications Policy, 32, 521-530 
Bass, J.M. \& Heeks, R. (2011) Changing computing curricula in African universities: evaluating progress and challenges via design-reality gap analysis, Electronic Journal of Information Systems in Developing Countries, 48(5), 1-39 https://www.ejisdc.org/ojs2/index.php/ejisdc/article/view/856

Bhatnagar, S.C. \& Singh, N. (2010) Assessing the impact of e-government: a study of projects in India, Information Technologies and International Development, 6(2), 109-127

Biddle, B.J. (1986) Recent development in role theory, Annual Review of Sociology, 12, 67-92

Boateng, R., Hinson, R., Galadima, R. \& Olumide, L. (2014) Preliminary insights into the influence of mobile phones in micro-trading activities of market women in Nigeria, Information Development, 30(1), 32-50

Burrell, J. \& Matovu, J. (2008) Livelihoods and the Mobile Phone in Rural Uganda, The Grameen Foundation USA, Washington, DC.

http://www.grameenfoundation.applab.org/uploads/burrell needs assessment final-1.pdf

Calandro, E. \& Wang, R. (2012) Predictors of mobile internet usage in 10 African countries, paper presented at $19^{\text {th }}$ ITS Biennial Conference, Bangkok 18-21 Nov http://www.econstor.eu/bitstream/10419/72487/1/741722321.pdf

Chepken, C.C. \& Muhalia, A. (2010) The poor and the mobile phone related spending. International Journal of Computing and ICT Research, 5(1), 10-19 http://www.ijcir.org/volume5-number1/Volume\%205\%20lssue1.pdf\#page=10

Chew, H.E., Levy, M. \& Ilavarasan, V. (2011) The limited impact of ICTs on microenterprise growth, Information Technologies and International Development, 7(4), 1-16 http://www.itidjournal.org/index.php/itid/article/viewFile/788/329

Chikweche, T. \& Fletcher, R. (2013) Customer relationship management at the base of the pyramid: myth or reality?, Journal of Consumer Marketing, 30(3), 295-309

Chipchase, J. (2009) Mobile Phone Practices \& The Design of Mobile Money Services for Emerging Markets. http://www.janchipchase.com/publications

Comninos, A., Esselaar, S., Ndiwalana, A. \& Stork, C. (2009) Airtime to cash: unlocking the potential of Africa's mobile phones for banking the unbanked, paper presented at IST-Africa 2009, Kampala, 6-8 May http://miun.diva-portal.org/smash/get/diva2:358905/FULLTEXT01

de Silva, H., Zainudeen, A. \& Ratnadiwakara, D. (2008) Perceived economic benefits of telecom access at the bottom of the pyramid in emerging Asia, paper presented at ICA 2008, Montreal, Canada, 20-21 May http://www-

personal.umich.edu/ parkyo/site/paper\%20abstracts/LIRNEasia ICApc Benefits at BOP v $\underline{21 . p d f}$ 
Denkinger, C.M., Grenier, J., Stratis, A.K., Akkihal, A., Pant-Pai, N. \& Pai, M. (2013) Mobile health to improve tuberculosis care and control: a call worth making, The International Journal of Tuberculosis and Lung Disease, 17(6), 719-727

DFID (1999) Sustainable Livelihood Guidance Sheet Section 2, Department for International Development, London http://www.livelihoods.org/info/guidance sheets pdfs/section2.pdf

DI (2013) Investments to End Poverty, Development Initiatives, Bristol, UK http://devinit.org/wp-content/uploads/2014/02/Investments-to-End-Poverty-highlights.pdf

Donner, J. (2007) Customer acquisition among small and informal businesses in urban India: Comparing face to face, interpersonal, and mediated channels, The Electronic Journal of Information Systems in Developing Countries, 32(3), 1-16

Donner, J. \& Escobari, M. (2010) A review of the research on mobile use by micro and small enterprises in developing countries, Journal of International Development, 22(5), 641-658

Duncan, J. (2013) Mobile network society? Affordability and mobile phone usage in Grahamstown East, Communicatio, 39(1), 35-52

Duncombe, R. (2007) Using the livelihoods framework to analyze ICT applications for poverty reduction through microenterprise, Information Technologies and International Development, 3(3), 81-100

Duncombe, R. (2012) An evidence-based framework for assessing the potential of mobile finance in sub-Saharan Africa, Journal of Modern African Studies, 50(3), 369-395

Duncombe, R. (2012) Understanding Mobile Phone Impact on Livelihoods in Developing Countries, Development Informatics working paper no.48, University of Manchester, UK http://www.seed.manchester.ac.uk/medialibrary/IDPM/working papers/di/di wp48.pdf

Etta, F.E. \& Parvyn-Wamahu, S. (2003) Information and Communication Technologies for Development: The Experience with Community Telecentres, IDRC, Ottawa http://www.idrc.ca/openebooks/006-3/

Ferreira, F.H.G. \& Lugo, M.A. (2012) Multidimensional Poverty Analysis, Policy Research Working Paper 5964, World Bank, Washington, DC https://openknowledge.worldbank.org/bitstream/handle/10986/3249/WPS5964.pdf

Flor, A.G. (2001) ICT and poverty: the indisputable link, paper presented at Third Asia Development Forum on Regional Economic Cooperation in Asia and the Pacific, Bangkok, 1114 Jun

Forestier, E., Grace, J. \& Kenny, D. (2002) Can information and communication technologies be pro-poor?, Telecommunications Policy, 26(11), 623-646 
Foster, C. (2013) Micro-enterprises and Inclusive Innovation: A Study of the Kenyan Mobile Phone Sector, PhD thesis, IDPM, University of Manchester, UK

Foster, C. \& Heeks, R.B. (2013) Innovation and scaling of ICT for the bottom-of-the-pyramid, Journal of Information Technology,28(4), 296-315

Gillwald, A. \& Stork, C. (2008) ICT Access and Usage in Africa, ResearchICTAfrica, Woodstock, South Africa http://www.researchictafrica.net/new/images/uploads/ria-policy-paper ictaccess-and-usage-2008.pdf

Godoy, J., Tortora, B., Sonneschein, J. \& Kendall, J. (2012) Payments and Money Transfer Behavior of Sub-Saharan Africans, Bill \& Melinda Gates Foundation, Seattle, WA http://papers.ssrn.com/sol3/papers.cfm?abstract id=2116449

GSMA (2013) Sub-Saharan Africa Mobile Economy, GSM Association, London

Hamade, S. (2012) The impact of mobile telephony on low-income communities in Lebanon, Digest of Middle East Studies, 21(1), 24-38

Harris, R. (2004) Information and Communication Technologies for Poverty Alleviation, UN Asia-Pacific Development Information Programme, Kuala Lumpur http://www.apdip.net/publications/iespprimers/eprimer-pov.pdf

Heeks, R.B. (1999) Information and Communication Technologies, Poverty and Development, Development Informatics working paper no.5, University of Manchester, UK http://www.seed.manchester.ac.uk/subjects/idpm/research/publications/wp/di/di-wp5/

Heeks, R.B. (2008) Researching ICT-Based Enterprise in Developing Countries, Development Informatics working paper no.30, University of Manchester, UK http://www.seed.manchester.ac.uk/subjects/idpm/research/publications/wp/di/di-wp30/

Heeks, R.B. (2009a) The godfather of ICT4D, and ICT4D's first computer, ICT4Dblog, 1 Jan http://ict4dblog.wordpress.com/2009/01/01/the-godfather-of-ict4d-and-ict4ds-firstcomputer/

Heeks, R.B. (2009b) The ICT4D 2.0 Manifesto: Where Next for ICTs and International Development, Development Informatics working paper no.42, University of Manchester, UK http://www.seed.manchester.ac.uk/subjects/idpm/research/publications/wp/di/di-wp42/

Heeks, R.B. (2009c) Beyond subscriptions: actual ownership, use and non-use of mobiles in developing countries, ICT4Dblog, 22 Mar

http://ict4dblog.wordpress.com/2009/03/22/beyond-subscriptions-actual-ownership-useand-non-use-of-mobiles-in-developing-countries/

Heeks, R.B. (2010) Development 2.0: the IT-enabled transformation of international development, Communications of the ACM, 53(4), 22-24 
Heeks, R.B. (2013) Information technology impact sourcing, Communications of the ACM, 56(12), 22-25

Heeks, R.B. (2014a) From the MDGs to the Post-2015 Agenda: Analysing Changing Development Priorities, Development Informatics working paper no.56, University of Manchester, UK

http://www.seed.manchester.ac.uk/subjects/idpm/research/publications/wp/di/di-wp56/

Heeks, R.B. (2014b) Future Priorities for Development Informatics Research from the Post2015 Development Agenda, Development Informatics working paper no.57, University of Manchester, UK http://www.seed.manchester.ac.uk/subjects/idpm/research/publications/wp/di/di-wp57/

Heeks, R.B. \& Arun, S. (2010) Social outsourcing as a development tool: the impact of outsourcing IT services to women's social enterprises in Kerala, Journal of International Development, 22(4), 441-454

Heeks, R.B. \& Duncombe, R. (2004) Ethical trade: issues in the regulation of global supply chains, in Leading Issues in Competition, Regulation and Development, P. Cook, C. Kirkpatrick, M. Minogue \& D. Parker (eds), Edward Elgar, Cheltenham, UK, 202-226

Heeks, R.B. \& Kanashiro, L.L. (2009a) Remoteness, Exclusion and Telecentres in Mountain Regions: Analysing ICT-Based "Information Chains" in Pazos, Peru, Development Informatics working paper no.38, University of Manchester, UK http://www.seed.manchester.ac.uk/subjects/idpm/research/publications/wp/di/di-wp38/

Heeks, R.B. \& Kanashiro, L.L. (2009b) Telecentres in mountain regions: a Peruvian case study of the impact of information and communication technologies on remoteness and exclusion, Journal of Mountain Science, 6(4), 320-330

Heeks, R.B. \& Kenny, C. (2002) The Economics of ICTs and Global Inequality, Development Informatics working paper no.10a, University of Manchester, UK http://www.seed.manchester.ac.uk/subjects/idpm/research/publications/wp/di/di-wp10a/

Heeks, R.B. \& Molla, A. (2009) Impact Assessment of ICT-for-Development Projects: A Compendium of Approaches, Development Informatics Working Paper no.36, University of Manchester, UK http://www.seed.manchester.ac.uk/subjects/idpm/research/publications/wp/di/di-wp36/

Heeks, R.B., Amalia, M., Kintu, R. \& Shah, S. (2013) Inclusive Innovation: Definition, Conceptualisation and Future Research Priorities, Development Informatics Working Paper 53, Centre for Development Informatics, University of Manchester, UK http://www.seed.manchester.ac.uk/subjects/idpm/research/publications/wp/di/

Huvila, I. (2008) Work and work roles: a context of tasks, Journal of Documentation, 64(6), 797-815 
iHub Research (2012) Mobile Phone Usage at the Kenyan Base of the Pyramid, iHub Research, Nairobi, Kenya http://blogs.worldbank.org/ic4d/files/ic4d/mobile phone usage kenyan base pyramid.pd $\underline{f}$

llavarasan, P.V. \& Levy, M.R. (2012) ICT access and use by microentrepreneurs in Mumbai, India, in: ICTD2012: Proceedings of the Fifth International Conference on Information and Communication Technologies and Development, J. Donner, B. Grinter \& G. Marsden (eds), 259-267

Impio, J., Masita-Mwangi, M., Macharia, L., Githinji, P. \& Sitati, M. (2008) Exploiting mobile technology in the African urban low-income informal music industry, in: Proceedings of $1^{\text {st }}$ International Conference on M4D, J.S. Pettersson (ed), Karlstad University, Sweden, 15-23 http://kau.diva-portal.org/smash/record.jsf?pid=diva2:200938

ITU (2014) ICT-Eye, International Telecommunication Union, Geneva http://www.itu.int/ITU-D/icteye/Indicators/Indicators.aspx

Jagun, A., Heeks, R.B. \& Whalley, J. (2008) The impact of mobile telephony on developing country micro-enterprise: a Nigerian case study, Information Technologies and International Development, 4(4), 47-65 http://itidjournal.org/itid/article/viewFile/310/142

James, J. (2013) Digital Interactions in Developing Countries, Routledge, Abingdon, UK

Jensen, M. \& Esterhuysen, A. (2001) The Community Telecentre Cookbook for Africa, UNESCO, Paris. http://unesdoc.unesco.org/images/0012/001230/123004e.pdf

Jensen, R. (2007) The digital provide: information (technology), market performance, and welfare in the South Indian fisheries sector, Quarterly Journal of Economics, CXXII(3), 879924

Katengeza, S.P., Okello, J.J., Mensah, E.R. \& Jambo, N. (2014) Effect of participation in ICTbased market information services on transactions costs and household income among smallholder farmers in Malawi, in: Technologies for Sustainable Development, J.-C. Bolay. S. Hostettler \& E. Hazboun (eds), Springer, Heidelberg, Germany, 197-207

Khan, F. \& Ghadially, R. (2010) Empowerment through ICT education, access and use, Journal of International Development, 22(5), 659-673

Kivunike, F.N., Ekenberg, L., Danielson, M. \& Tusubira, F.F. (2011) Perceptions of the role of ICT on the quality of life in rural communities in Uganda, Information Technology for Development, 17(1), 61-80

Kleine, D. (2013) Technologies of Choice?: ICTs, Development, and the Capabilities Approach, MIT Press, Cambridge, MA 
Kliner, M., Knight, A., Mamvura, C., Wright, J. \& Walley, J. (2013) Using no-cost mobile phone reminders to improve attendance for HIV test results, Infectious Diseases of Poverty, 2(12), 1-7

Knowledge@Wharton (2010) It Takes a Village: The Rise of Rural BPO, Knowledge@Wharton, University of Pennsylvania, Philadelphia, PA http://knowledge. wharton.upenn.edu/india/article.cfm?articleid $=4450$

Komunte, M., Rwashana, A.S. \& Nabukenya, J. (2012) Comparative analysis of mobile phone usage among women entrepreneurs in Uganda and Kenya, African Journal of Computing and ICT, 5(5), 74-86

Lakshmi Ratan, A., Satpathy, S., Zia, L., Toyama, K., Blagsvedt, S., Singh Pawar, U. \& Subramaniam, T. (2009) Kelsa+: digital literacy for low-income office workers, in: ICTD2009 Proceedings, R. Heeks \& R. Tongia (eds), Carnegie Mellon University, Qatar, 150-162 http://www.ictd2009.org/documents/ICTD2009Proceedings.pdf

Light, A. (2010) Bridging global divides with tracking and tracing technology, Pervasive Computing, 9(2), 28-36

Madon, S. \& Sharanappa, S. (2013) Social IT outsourcing and development: theorising the linkage, Information Systems Journal, 23, 381-399

Makoza, F. \& Chigona, W. (2012) The livelihood outcomes of ICT use in microenterprises, Electronic Journal of Information Systems in Developing Countries, 53(1), 1-16 https://www.ejisdc.org/Ojs2/index.php/ejisdc/article/viewFile/1009/424

Malik, F., Morgan, S. and Nicholson, B. (2013) Assessing the social development potential of impact sourcing, Globdev 2013, paper 4 http://aisel.aisnet.org/globdev2013/4/

Manyozo, L. (2006) Manifesto for development communication: Nora Quebral and the Los Baños School of Development Communication, Asian Journal of Communication, 16(1), 79-99

Martin, B.L. \& Abbott, E. (2011) Mobile phones and rural livelihoods, Information Technologies and International Development, 7(4), 17-34

Mawona, A. \& Mpogole, H. (2013) ICT and financial inclusion: adoption of mobile phone banking among small business owners in Iringa, Tanzania, paper presented at IST-Africa 2013, Nairobi, Kenya, 28-31 May

Mehta, B.S. (2013) Capabilities, Costs, Networks and Innovations: Impact of Mobile Phones in Rural India, Capturing the Gains Working Paper 29, Institute for Human Development, New Delhi, India http://www.capturingthegains.org/pdf/ctg-wp-2013-29.pdf 
Mpogole, H., Usanga, H. \& Tedre, M. (2008) Mobile phones and poverty alleviation, paper presented at $1^{\text {st }}$ International M4D Conference, Karlstad, Sweden, 11-12 Dec http://ict4dblog.files.wordpress.com/2008/12/m4d-mpogole-final-paper4.doc

Mwangi, G.W. \& Acosta, F.R. (2013) Mobile phones and the growth of microenterprises, DLSU Business \& Economics Review, 23(1), 105-135

Neuwirth, R. (2011) Global bazaar, Scientific American, Sept, 56-63

Norris, P. \& Inglehart, R. (2013) Digital divide, in: Handbook on the Digital Creative Economy, R. Towse \& C. Handka (eds), Edward Elgar, Cheltenham, UK, 90-104

OECD (2013) OECD Communications Outlook 2013, OECD, Paris

Pade-Khene, C., Mallinson, B. \& Sewry, D. (2011) Sustainable rural ICT project management practice for developing countries, Information Technology for Development, 17(3), 187-212

Pearce, K.E. \& Rice, R.E. (2013) Digital divides from access to activities: comparing mobile and personal computer Internet users, Journal of Communication, 63(4), 721-744

Postigo, H. (2011) Questioning the Web 2.0 discourse: social roles, production, values, and the case of the human rights portal, The Information Society, 27(3), 181-193

Rahman, A., Abdullah, M.N., Haroon, A. \& Tooheen, R.B. (2013) ICT impact on socioeconomic conditions of rural Bangladesh, Journal of World Economic Research, 2(1), 1-8

Rangaswamy, N. \& Nair, S. (2012) The PC in an Indian urban slum: enterprise and entrepreneurship in ICT4D 2.0, Information Technology for Development, 18(2), 163-180

Ravallion, M. (2004) Pro-Poor Growth: A Primer, Policy Research Working Paper 3242, World Bank, Washington, DC

ResIST (2009) Distributional Assessment of Emerging Technologies, WP4 Policy Paper, Researching Inequality through Science and Technology, University of Oxford http://www.resistresearch.net/cms/site/docs/WP4\%20Policy\%20Paper\%20Del\%20\%2025 Final Complete.pd $\underline{f}$

Richardson, D., Ramirez, R. \& Haq, M. (2000) Grameen Telecom's Village Phone Programme in Rural Bangladesh, TeleCommons Development Group, Guelph, ON http://www.telecommons.com/villagephone/finalreport.pdf

Sen, A. (1985) Well-being, agency and freedom, The Journal of Philosophy, LXXXII(4), 169221 
Sey, A., Coward, C., Bar, F., Sciadas, G., Rothschild, C. \& Koeple, L. (2013) Connecting People for Development, Technology and Social Change Group, University of Washington, Seattle, WA

Sivasubramaniam, K. (1991) Kattumaram Fisheries and Fisherfolk, FAO, Bay of Bengal Programme, Madras http://www.fao.org/docrep/007/ae449e/ae449e00.HTM

Smith, M. (2010) A Technology of Poverty Reduction for Non-Commercial Farmers? Mobile Phones in Rural North Ghana, BA dissertation, unpublished, University of Oxford, UK

Srinivasan, J. \& Burrell, J. (2013) Revisiting the fishers of Kerala, India, in: ICTD2013: Proceedings of the Sixth International Conference on Information and Communication Technologies and Development, J. Donner \& T. Parikh (eds), 56-66

Stork, C., Calandro, E. \& Gillwald, A. (2013) Internet going mobile: internet access and use in 11 African countries, Info, 15(5), 34-51

Subrahmanyan, S. \& Gomez-Arias, J.T. (2008) Integrated approach to understanding consumer behavior at bottom of pyramid, Journal of Consumer Marketing, 25(7), 402-412

TBC (2013) The State of Broadband 2013, The Broadband Commission http://www.broadbandcommission.org/Documents/bb-annualreport2013.pdf

UNCTAD (2006) Information Economy Report 2006, UN Conference on Trade and Development, Geneva http://www.unctad.org/en/docs/sdteecb20061 en.pdf

UNCTAD (2010) Information Economy Report 2010, UN Conference on Trade and Development, Geneva http://unctad.org/en/docs/ier2010 embargo2010 en.pdf

UNDESA (2012) World Urbanization Prospects, UN Department of Economic and Social Affairs, New York, NY

Wakunuma, K. (2007) Mobiles reinforce unequal gender relations in Zambia, Insights, 69, p3 http://mobileactive.org/files/file uploads/insights69.pdf

Walia, V. \& Goodman, J. (2007) Airtime transfer services in Egypt, in: The Transformational Potential of m-Transactions, Vodaphone Policy Paper Series, No.6, Vodaphone, 30-35. http://www.vodaphone.com/m-transactions

Walton, M., Hassreiter, S., Marsden, G. \& Allen, S. (2012) Degrees of sharing: proximate media sharing and messaging by young people in Khayelitsha, in: Proceedings of $\mathrm{MobileHCl}$ 2012, 403-412 http://pubs.cs.uct.ac.za/archive/00000789/01/p403.pdf

World Bank (2012) Maximizing Mobile, World Bank, Washington, DC

Zainudeen, A. \& Ratnadiwakara, D. (2011) Are the poor stuck in voice?, Information Technologies and International Development, 7(3), 45-59 